\title{
C-1 \\ CHARACTERISTICS OF STREAMFLOW AND GROUND-WATER CONDITIONS IN THE BOISE RIVER VALLEY, IDAHO
}

U.S. GEOLOGICAL SURVEY

Water-Resources Investigations 38-74

Prepared in cooperation with

the Idaho Department of Water Resources

and the Corps of Engineers, U.S. Army,

Walla Walla District

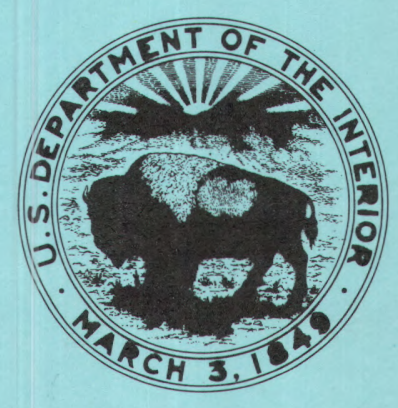


4. Title and Subtitle

"Characteristics of streamflow and ground-water conditions in Boise River valley, Idaho"

5. Report Date approved September 1974 6.

7. Author(s)

C. A. Thomas and N. P. Dion

9. Performing Organization Name and Address

U.S. Geological Survey, WRD

Box 036, FBUSCH

550 West Fort Street

Boise, Tdaho 83724

12. Sponsoring Organization Name and Address

U.S. Geological Survey, WRD

Box 036, FBUSCH

550 West Fort Street

8. Performing Organization Rept. No. WRI $-38-74$

10. Project/Task/Work Unit No.

Boise, Idaho 83724

11. Contract/Grant No.

15. Supplementary Notes Prepared in cooperation with the Idaho Department of Water Resources and the U.S. Army, Corps of Engineers, Walla Walla District

16. Abstracts The quantity, quality, and distribution in time of streamflow in Boise River below Lucky Peak Lake are drastically affected by storage reservoirs, diversions for irrigation, and by domestic, industrial, and agricultural wastes. Reservoirs usually fill during the nonirrigation season, and streamflow for several miles below Lucky Peak Lake is very low, sometimes less than 10 cubic feet per second (0.28 cubic meters per second). On November 18-19, 1971, when the gates at Lucky Peak Dam were closed, inflow to the Boise River in the study reach totaled $1010 \mathrm{ft} / \mathrm{s}$. Practically all inflow was discharged ground water. During the growing season, several thousands of $\mathrm{ft}^{3} / \mathrm{s}$ are released from Lucky Peak Lake, but diversions reduce the flows to near zero below some large diversion points in the study reach. Characteristics of streamflow are described by duration curves, duration hydrographs, and low-flow and high-flow frequency curves.

Water released from Lucky Peak Lake is of excellent quality. Dissolved solids are usually less than 80 milligrams per liter. Discharged ground water increases the dissolved solids in the river downstream to 400 milligrams per liter or more when dilution from Lucky Peak Lake is slight. Other measures of water quality 1ikewise show the deterioration in a downstream direction in the study reach.

17. Key Words and Document Analysis. 17a. Descriptors

Regulated streamflow, Natural streamflow, Flow characteristics, Low flow, Floods, Flood control, Duration curves, Frequency analyses, Variability Irrigation water, Consumptive use, Return flow, Aquifers, Drainage channels, Drainage water, Ground-water discharge, Water quality, Water temperature, Dissolved solids

17b. Identifiers/Open-Ended Terms

Lucky Peak Lake, Boise, Idaho, Snake River

17c. COSATI Field/Group

\begin{tabular}{|c|c|c|}
\hline 18. Availability Statement No restriction on distribu- & $\begin{array}{l}\text { 19. Security Class (This } \\
\text { Report) } \\
\text { UNCLASSIFIED }\end{array}$ & 21. No. of Pages \\
\hline $\begin{array}{l}\text { Available from National Technical } \\
\text { Information Service, Springfield, VA, } 2 \frac{1}{21} 5\end{array}$ & $\begin{array}{l}\text { 20. Security Class (This } \\
\text { Page } \\
\text { UNCLASSIFIED }\end{array}$ & 22. Price \\
\hline
\end{tabular}




\section{CHARACTERISTICS OF STREAMFLOW AND GROUND-WATER CONDITIONS IN THE BOISE RIVER VALLEY, IDAHO}

By C. A. Thomas and N.P. Dion

\section{U.S. GEOLOGICAL SURVEY}

Prepared in cooperation with the Idaho Department of Water Resources and the Corps of Engineers, U.S. Army, Walla Walla District

\section{CIBRARY}
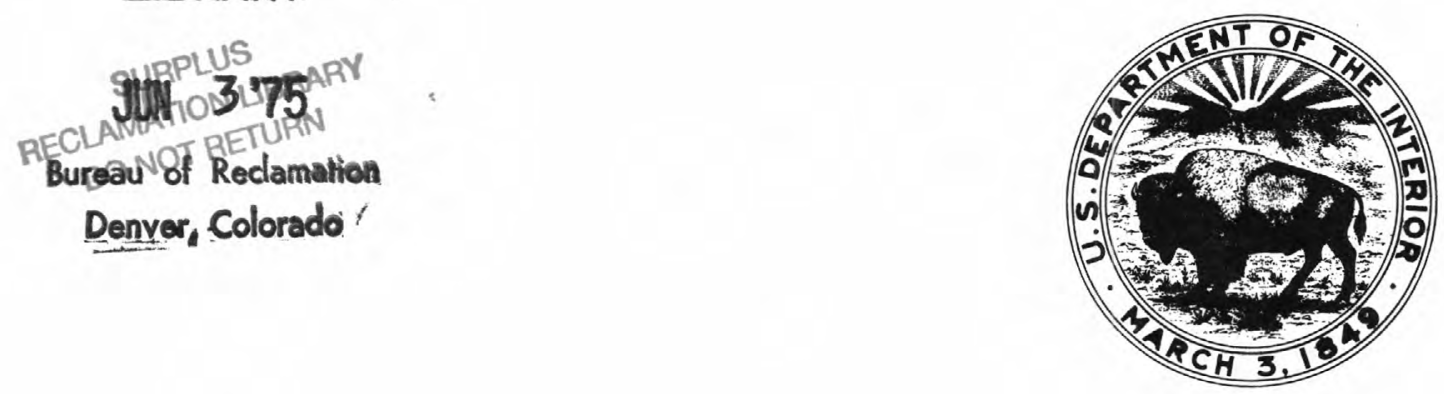
UNITED STATES DEPARTMENT OF THE INTERIOR

\author{
Rogers C. B. Morton, Secretary \\ GEOLOGICAL SURVEY
}

V. E. McKelvey, Director

For additional information write to:

U.S. Geological Survey

Box 036 , FBUSCH

550 West Fort Street

Boise, Idaho 83724 


\section{CONTENTS}

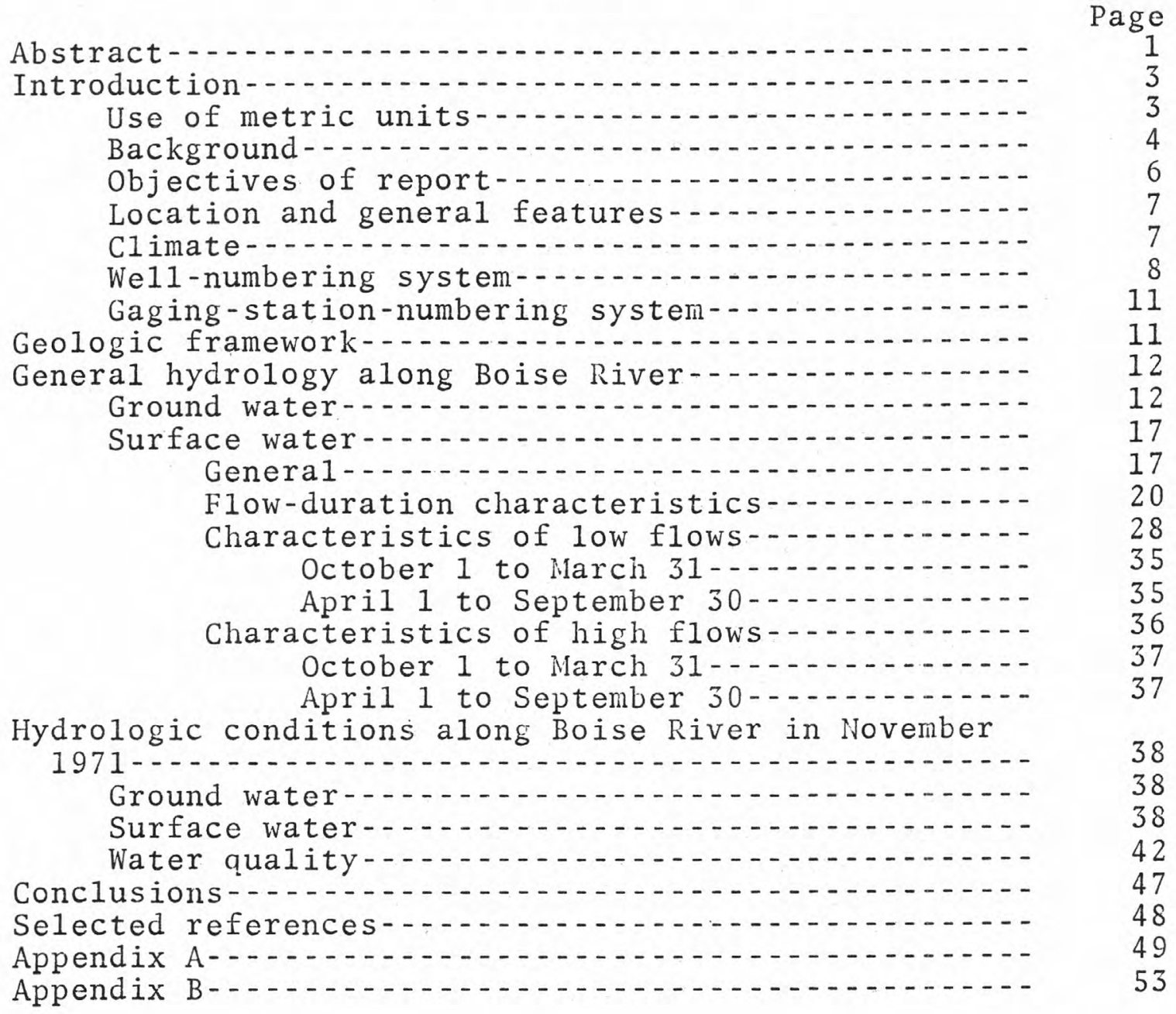


Figure 1. Map of Idaho showing area covered by

Page

this report-..................... 5

2. Map showing generalized geology-..-.-.-In pocket

3. Graph showing mean monthly temperature and precipitation at Boise-........ 9

4. Diagram showing we11-numbering system-.-.- 10

5. Map showing altitude of ground-water table-In pocket

6. Hydrographs of selected observation wells- 15

7. Hydrographs of monthly streamflow-.....-. 19

8. Map of the Boise River below Lucky Peak

Dam showing stream discharge and chemical character of the surface water in November 1971-........................ pocket

9. Flow-duration curves for period October 1 to March $31 \ldots 21$

10. Flow-duration curves for period April 1

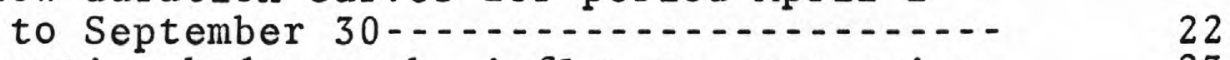

11. Duration hydrograph, inflow to reservoirs- 23

12. Duration hydrograph, Boise River near Boise . . . . . . 2. 24

13. Duration hydrograph, Boise River at Boise- 25

14. Duration hydrograph, Boise River at Notus- 26

15. High-flow and low-flow frequency curves, Boise River near Boise, October 1 to March $31 . . . .29$

16. High-flow and low-flow frequency curves, Boise River near Boise, April 1 to September 30.....................................

17. High-flow and low-flow frequency curves, Boise River at Boise, October 1 to

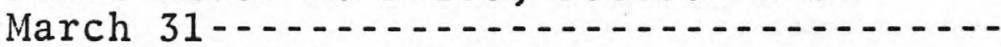

18. High-flow and low-flow frequency curves, Boise River at Boise, April 1 to

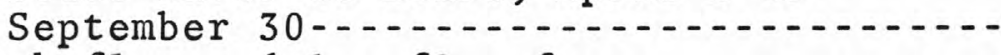

19. High-flow and low-flow frequency curves, Boise River at Notus, October 1 to

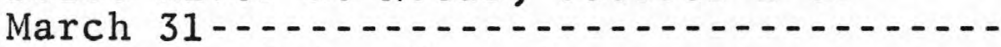

20. High-flow and low-flow frequency curves, Boise River at Notus, April 1 to September 30.........................................

21. Graph of cumulative inflow to the Boise

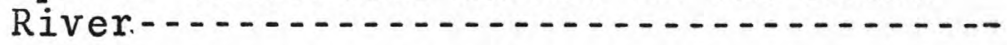


Table 1. Summary of chemical analyses of ground

Page

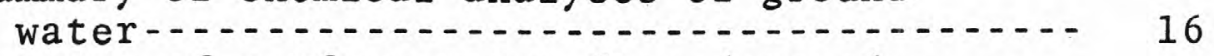

2. Summary of surface-water flow (groundwater discharge) in the Boise River

valley, November 18-19, 1971-.......... 40

3. Summary of standard chemical analyses of surface water in Boise River and

tributaries ..... 44 



\section{CHARACTERISTICS OF STREAMFLOW AND GROUND-WATER}

CONDITIONS IN THE BOISE RIVER VALLEY, IDAHO

By C. A. Thomas and N. P. Dion

\section{ABSTRACT}

Works of man drastically affect the quantity, quality, and distribution in time of the streamflow in the reach of the Boise River from Lucky Peak Lake to the mouth. Nearly onefourth of the people in Idaho live in the lower Boise River valley, and the impact on water quality of the domestic, industrial, and agricultural wastes discharged into the river is considerable. Four large reservoirs have a combined capacity of 1.2 million acre-feet ( 1.48 cubic kilometers), or about 60 percent of the mean annual outflow from Lucky Peak Lake. Canals divert an average of nearly 1.8 million acre-feet $(2.2$ cubic kilometers) annually for irrigation of about 350,000 acres $(1,400$ square kilometers). Of this diversion, about 700,000 acre-feet ( 0.9 cubic kilometers) is used consumptively, and about 300,000 acre-feet ( 0.4 cubic kilometers) is stored in the ground-water system. Historically, irrigation has been a high-priority use, and optimal flow rates for irrigation are not always optimal for other uses.

When Lucky Peak Lake is filling, releases are sometimes very small. Diversions are nil, and the river in the study reach gains several hundred cubic feet per second from ground-water discharge into the main channel and a network of tributaries and drains.

During the irrigation season, the flow characteristics are significantly different. Flows of several thousands of cubic feet per second are released from Lucky Peak Lake, but diversions into the canals reduce these flows in the study reach. Flows of 100 cubic feet per second ( 3 cubic meters per second) or less are common near Star and at Notus.

Continuous records of discharge for considerable periods of time are available below Lucky Peak Lake at gaging stations near Boise (immediately below the dam), at Boise, and at Notus. The value of streamflow records for planning and water management is increased by statistical analyses that portray various 
streamflow statistics. Low-flow, high-flow, and flow-duration characteristics are described in the report by duration curves, duration hydrographs, and low-flow and high-flow frequency curves.

Management of the storage space for flood control in Lucky Peak Lake and Anderson Ranch Reservoir has effectively reduced peak flows. During the irrigation season, diversions, consumptive use, and ground-water storage further reduce the peak flows in the study reach. Peaks have been reduced to less than half what natural peaks would have been, and several potentially damaging floods have been averted. Intermediate high flows have been maintained for longer periods. These changes in flow regimes have been accompanied by changes in sediment transport and deposition. The channel has aggraded, and the carrying capacity of the channel has been reduced.

To determine characteristics of the inflow of ground water to the river, discharge measurements were made at 16 sites on the main stem and on 20 drainage channels between Lucky Peak Lake and the mouth on November 18-19, 1971, when the gates at Lucky Peak Dam were completely closed. Practically all of the total inflow into this reach of the river, about 1,010 cubic feet per second (28 cubic meters per second), was from discharged ground water.

Ground-water levels were measured in 86 wells near the Boise River on November 18-19, 1971. At this time, water levels were only slightly lower than the high for the year, which occurs about October 15, at the end of the irrigation season. The water table slopes toward the river and the larger drainage channels.

The quality of the water flowing from Lucky Peak Lake is excellent. Dissolved-solids concentrations in samples collected during 1965-72 at the outlet ranged from 38 to 82 milligrams per liter and bore little relation to discharge. Water temperatures seldom exceed $18^{\circ} \mathrm{C}$ (Celsius), $65^{\circ} \mathrm{F}$ (Fahrenheit).

The quality of the water deteriorates downstream. Samples collected at Notus, for example, showed a range in dissolvedsolids concentrations from 90 milligrams per liter to more than 400 milligrams per 1iter, depending largely on how much the ground-water discharge was diluted by releases of fresher water from Lucky Peak Lake. Water temperatures as high as $29^{\circ} \mathrm{C}\left(84^{\circ} \mathrm{F}\right)$ have been recorded. In general, biochemical-oxygen demand and nutrients increase, and dissolved-oxygen concentration decreases in a downstream direction in the study reach of the Boise River. 
Samples collected on November 18-19, 1971, showed dissolved-solids concentrations of more than 1,000 milligrams per liter in some of the drainage channels, calcium carbonate type water at Lucky Peak Dam outlet, and sodium bicarbonate type water in the lower end of the study reach. Nitrogen and phosphorus concentrations increased about fivefold in the reach, but no concentrations were at objectionable levels for most uses of water, although some concentrations were high enough to support algal blooms if temperatures and other factors had been suitable. Biochemica1-oxygen demand and dissolved-oxygen concentrations were not at levels hazardous for fish when the samples were taken.

\section{INTRODUCTION}

\section{Use of Metric Units}

The International System of Units (SI Units) is being adopted for use in reports prepared by the U.S. Geological Survey. To assist readers of this report in understanding and adapting to the new system, many of the measurements reported herein are given in both units. The factors listed below are presented as an aid to conversion from one system of units to another.

Multiply English units

inches (in)
feet ( $f t$ )
miles (mi)
acres
square miles $\left(\mathrm{mi}^{2}\right)$
gallons (gal)
acre-feet (acre- $f t$ )
million acre-feet

(cfs)

cubic feet per second $\left(\mathrm{ft}^{3} / \mathrm{s}\right)$

gallons per minute (gal/min)
By

To obtain SI units

\section{Length}

$\begin{array}{ll}25.4 & \text { millimeters (mm) } \\ .3045 & \text { meters }(\mathrm{m}) \\ 1.609 & \text { kilometers }(\mathrm{km}) \\ \text { Area } & \end{array}$

4047 .4047
.004047

square meters $\left(\mathrm{m}^{2}\right)$ hectares (ha) square kilometers $\left(\mathrm{km}^{2}\right)$

2.590

square kilometers $\left(\mathrm{km}^{2}\right)$

Volume

3.785
$3.785 \times 10^{-3}$

liters (1)

cubic meters $\left(\mathrm{m}^{3}\right)$

1233

cubic meters $\left(\mathrm{m}^{3}\right)$

1.233

cubic kilometers $\left(\mathrm{km}^{3}\right)$

Flow

28.32 .02832

liters per second ( $1 / \mathrm{s})$ cubic meters per second $\left(\mathrm{m}^{3} / \mathrm{s}\right)$

.06309 


\section{Background}

Downstream from Lucky Peak Lake (fig. 1), the Boise River flows through the most populous area in Idaho. Nearly one-fourth of the people in the State live in the lower Boise River valley. An important segment of the valley's economy is irrigated agriculture, which is largely dependent on water obtained from the river and its reservoirs.

Diversions of water for the irrigation of crops began in about 1863. In 1906, the water in the system was adjudicated by the "Stewart Decree," which recognized rights to diversion of $2,825 \mathrm{ft}^{3} / \mathrm{s}\left(80 \mathrm{~m}^{3} / \mathrm{s}\right)$ for irrigation. In addition, the streamflow is used extensively for recreational purposes and for the dilution of domestic, agricultural, and industrial wastes.

Decreed rights far exceed the natural river flow during a part of most irrigation seasons. Four major reservoirs are available in the Boise River system to store the streamflow and to regulate the available supply. The two earth embankments forming Lake Lowell (fig. 1) were completed in 1908; Arrowrock Dam was completed in 1915 and raised 5 feet in 1937; Anderson Ranch Dam was completed in 1945; and Lucky Peak Dam was completed in October 1954. The four reservoirs created have a combined storage capacity of nearly 60 percent of the average annual runoff occurring above Lucky Peak Lake. Streamflow from Lucky Peak Lake has been almost completely controlled since 1954. However, space in Arrowrock Reservoir and Lake Lowe11 is owned by the irrigators and is operated primarily to fill irrigation needs. Anderson Ranch Reservoir is operated for power, flood control, and irrigation. Lucky Peak Lake is operated to fill multiple needs, including flood control and summer recreation. River flows are not always optimal for all uses, including fishery, recreation, and, perhaps, maintenance of a properly graded and shaped stream channel.

Thirty-seven principal canals and about 15 laterals (private or small diversions) divert water from the Boise River for irrigation during the growing season. The largest of the diversions, the New York Canal, feeds water directly into irrigation laterals. In addition, it transfers water a distance of about $37 \mathrm{mi}(60 \mathrm{~km})$ from Diversion

Natural river flow is used in this report to indicate the flows that would occur if there were no regulation of the river by upstream reservoirs. 


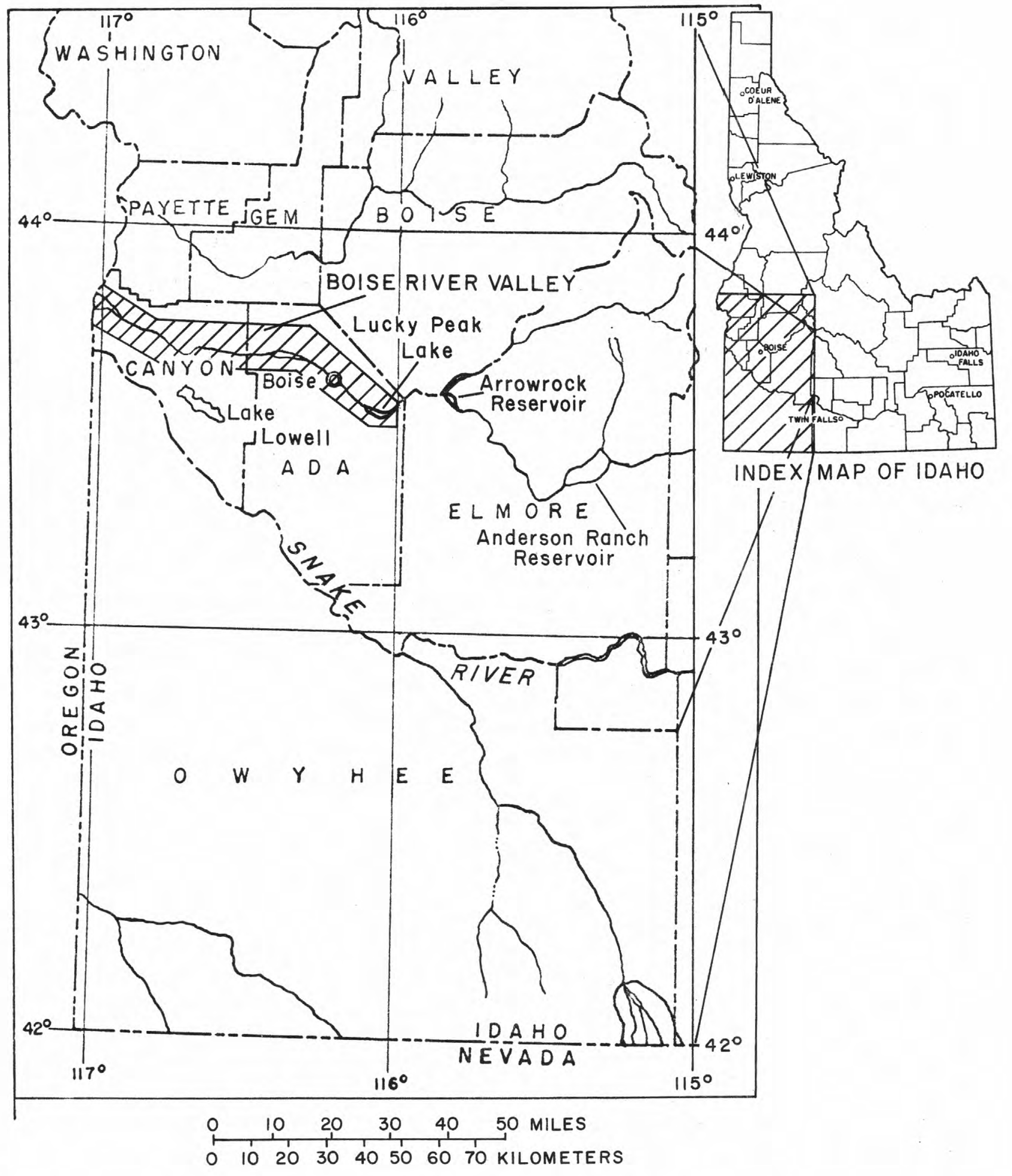

FIGURE 1.--Index map showing area covered by this report. 
Dam on the Boise River to Lake Lowe11, which is an integral part of the Boise River storage system.

Abrupt changes in flow that regularly occur in the study reach result from regulation to satisfy irrigation and other needs. On about October 15, when irrigation diversions cease and the reservoirs begin to refill, flow from Lucky Peak Lake is reduced sharply, usually by $3,500 \mathrm{ft}^{3} / \mathrm{s}\left(100 \mathrm{~m}^{3} / \mathrm{s}\right)$ or more. At this time, flow in the upper end of the river reach decreases abruptly, sometimes to $1 \mathrm{ft}^{3} / \mathrm{s}\left(0.03 \mathrm{~m}^{3} / \mathrm{s}\right)$ or 1ess. However, because downstream diversions are also stopped at about this time, return flows entering the river raise streamflow to the extent that flows of several hundreds of cubic feet per second occur at the lower end of the reach. Although large releases from Lucky Peak Lake are made during each nonirrigation season to fill Lake Lowell, releases to Boise River below Diversion Dam at the head of the New York Canal may still be very small. However, when reservoir impoundments and accumulated snowpacks indicate surplus flows can be expected, large releases are made in the winter period to provide reservoir space for flood control. At times, these releases are of sufficient magnitude to cause flooding in the lower reaches of the river. During most years, on about April 15 when the irrigation season begins, sharp increases of $1,000 \mathrm{ft}^{3} / \mathrm{s}$ $\left(28 \mathrm{~m}^{3} / \mathrm{s}\right)$ or more occur immediately below Diversion Dam and in the river reach past Boise City. However, diversions for irrigation reduce the flows downstream to the point that flows near zero can occur at times throughout the irrigation season near Star. Generally, return flows below Star maintain flow in the river sufficient to fill diversion needs.

\section{Objectives of Report}

A primary function of the U.S. Geological Survey in Idaho is to study and report on the water resources of the State in cooperation with various governmental agencies. In 1971 , a number of Federal and State agencies, under the auspices of the U.S. Army Corps of Engineers, participated in a study of the surface-water resources of the 64-mi $(103-\mathrm{km})$ reach of the Boise River extending from Lucky Peak Dam to its confluence with the Snake River. Participation by the Geological Survey in this study consisted of (1) the analysis of a large amount of the pertinent basic water data it has collected in the Boise River valley since 1895; and (2) the collection and analysis of a number of streamflow measurements, ground-water-level measurements, and water-quality samples during a time (Nov. 18-19, 1971) when the gates in Lucky Peak Dam were closed, and flow into and from the river was minimal. 
The purposes of this report are to describe (1) the general streamflow characteristics of the lower Boise River utilizing historical data in the files of the U.S. Geological Survey; (2) the streamflow and water-quality characteristics of the lower Boise River as measured during a period of minimal flows on November 18-19, 1971, when the gates at Lucky Peak Dam were closed; and (3) general groundwater conditions in the Boise River valley.

\section{Location and General Features}

The lower portion of the Boise River system described in this report extends from Lucky Peak Dam to the river's confluence with the Snake River (fig. 1) and is in the Columbia Plateau physiographic province (Fenneman, 1931, pl. 1). The area studied, which includes a $64-\mathrm{mi}(103-\mathrm{km})$ stretch of the Boise River and a narrow strip of its drainage basin, occupies about $470 \mathrm{mi}^{2}\left(1200 \mathrm{~km}^{2}\right)$ in Ada and Canyon Counties, Idaho (fig. 1).

The part of the Boise River valley that lies within the study area is below an altitude of about $3,000 \mathrm{ft}(900 \mathrm{~m})$ and includes a broad, alluvial-floored valley and several steplike terraces, or benches (fig. 2). Although these river terraces occur on both the north and south sides of Boise River, they are much better developed and are more continuous on the south side. Foothills reaching down from the nearby mountains terminate quite abruptly along the north side of the flat valley floor. The valley floor slopes to the northwest at about $10 \mathrm{ft} / \mathrm{mi}(20 \mathrm{~m} / \mathrm{km})$, a slope of 0.0019 . The altitude of the valley floor near the mouth of the Boise River is about $2,200 \mathrm{ft}(670 \mathrm{~m})$.

The study area is drained by several large and small tributaries and by an intricate network of canals and drains in addition to the Boise River. Tributary streams, especially outside the irrigated acreages, are dry during much of the year. Streams flowing off the Boise front, northeast of the river, generally flow southwesterly; south of Boise River, the streams have a northwesterly trend.

Principal cities and towns in the area are Boise, Garden City, Meridian, Eagle, and Star in Ada County; and Middleton, Caldwe11, Notus, and Parma in Canyon County.

\section{C1imate}

The Boise River valley has a temperate climate that is characterized by cool, wet winters and warm, dry summers. 
Large diurnal temperature fluctuations are normal, and the warm season usually arrives rather abruptly. A part of the winter precipitation is in the form of snow, but the snow cover is characteristically thin and seldom remains on the ground for long periods. Compared with conditions nationwide, the average relative humidity at Boise is low ( 58 percent) and the percentage of maximum possible sunshine is high (67 percent).

The mean annual temperature at Boise is $10.6^{\circ} \mathrm{C}\left(51.1^{\circ} \mathrm{F}\right)$. January has the lowest mean monthly temperature, $-1.6^{\circ} \mathrm{C}$ $\left(29.1^{\circ} \mathrm{F}\right)$, and July the highest, $24.0^{\circ} \mathrm{C}\left(75.2^{\circ} \mathrm{F}\right),(\mathrm{fig} .3)$. The average date of the last freeze in the spring is May 6; that of the first freeze in the fall is October 12, for an average freeze-free growing season of 159 days (Stev1ingson and Everson, 1968). To convert degrees Celsius ( $T_{\text {f }}$ ) to degrees Fahrenheit $\left(\mathrm{T}_{f}\right)$, the following formula is applicable:

$$
\mathrm{T}_{\mathrm{f}}=1.8 \mathrm{~T}_{\mathrm{C}}+32 \text {. }
$$

The mean annual precipitation at Boise is 11.42 in $(20 \mathrm{~mm})$. August has the lowest, 0.16 in $(4 \mathrm{~mm})$, and February the highest, 1.33 in ( $34 \mathrm{~mm})$, mean monthly precipitation. The amount of precipitation during the average freeze-free growing season is only about 2.9 in $(74 \mathrm{~mm})$, or 25 percent of the annual total.

Winds of destructive force are rare in the Boise River valley. Southeasterly winds predominate and average $9 \mathrm{mi} / \mathrm{hr}$ (14 km/hr). Northwesterly winds are nearly as common during some seasons.

\section{We11-Numbering System}

The we11-numbering system used by the U.S. Geological Survey in Idaho indicates the location of wells within the official rectangular subdivision of the public lands, with reference to the Boise base line and meridian. The first two segments of the number designate the township and range. The third segment gives the section number, followed by three letters and a numeral, which indicate the quarter section, the $40-\operatorname{acre}\left(0.16-\mathrm{km}^{2}\right)$ tract, the $10-\operatorname{acre}\left(0.04-\mathrm{km}^{2}\right)$ tract, and the serial number of the well within the tract, respectively. Quarter sections are lettered a, b, c, and d in counterclockwise order from the northeast quarter of each section (fig. 4). Within the quarter sections, 40-acre $\left(0.16-\mathrm{km}^{2}\right)$ and $10-\operatorname{acre}\left(0.04-\mathrm{km}^{2}\right)$ tracts are lettered in the same manner. Well $3 \mathrm{~N}-2 \mathrm{E}-8 \mathrm{adcl}$ is in the SW $\frac{1}{4} \mathrm{SE} \frac{1}{4} \mathrm{NE} \frac{1}{4} \mathrm{sec} .8$, T. 3 N., R. 2 E., and is the first well visited in that tract. 


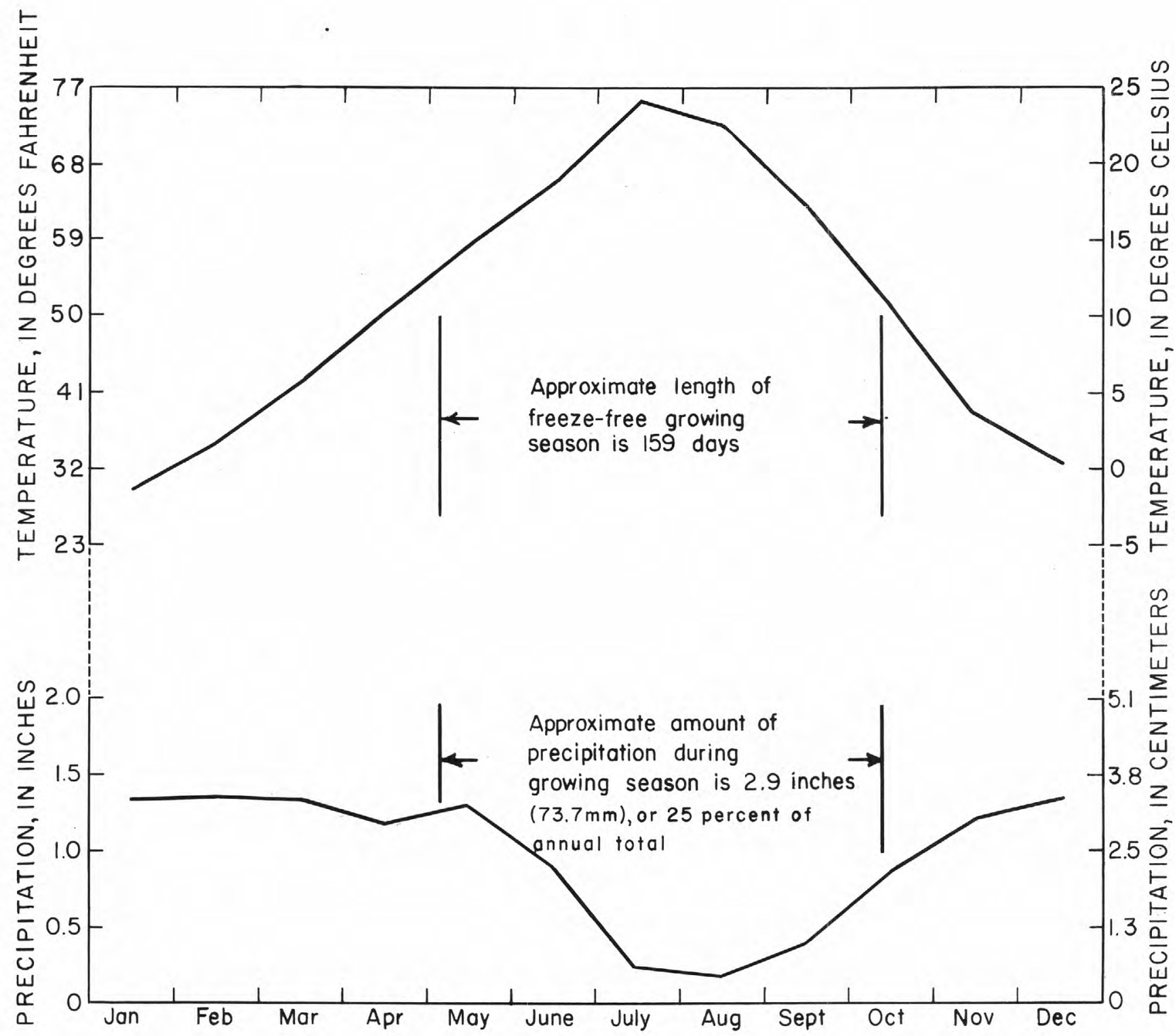

FIGURE 3.--Mean monthly temperature and precipitation at Boise Municipal Airport (based on data from National Weather Service for 1939-60). 


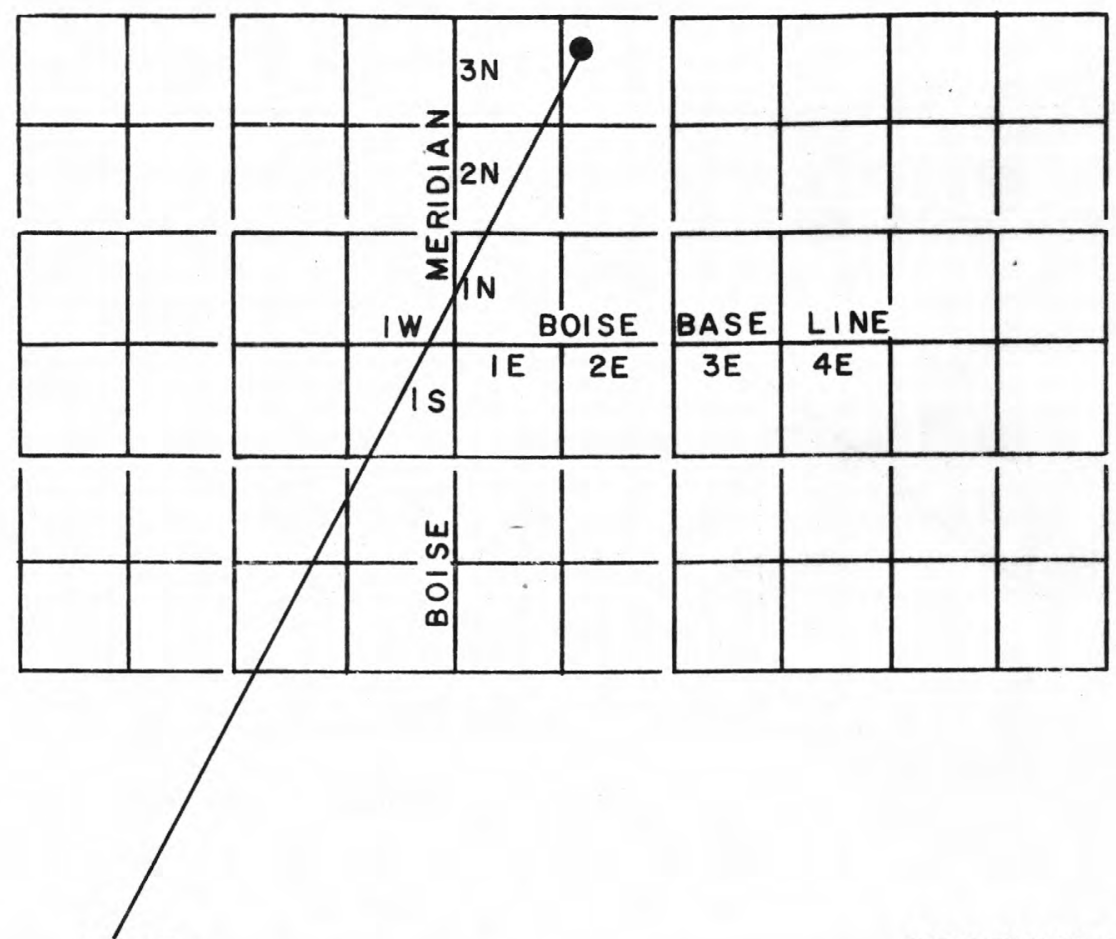

R. $2 E$.

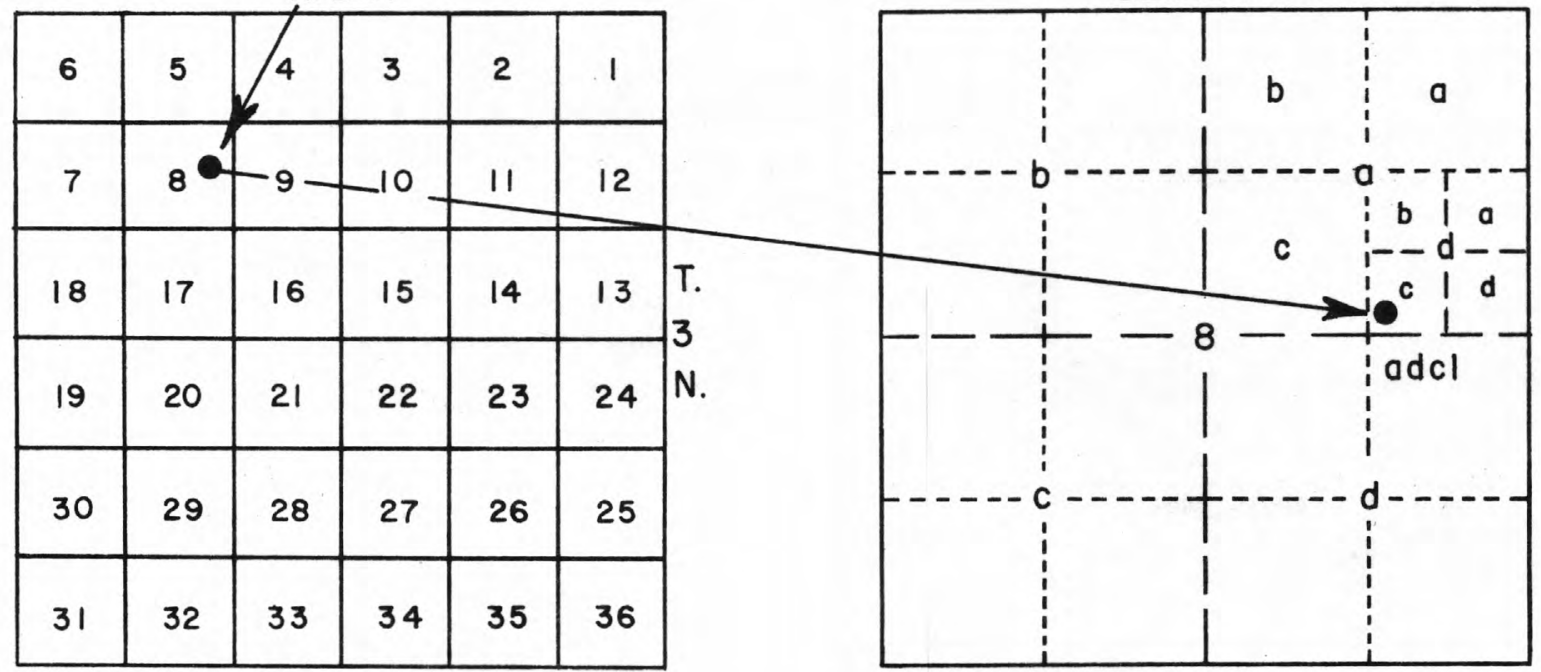

FIGURE 4.--Diagram showing well-numbering system. (Using well $3 \mathrm{~N}-2 \mathrm{E}-8 \mathrm{adcl}$ ) 
Each gaging station and partial-record station in Idaho has been assigned a number in downstream order in accordance with the permanent numbering system used by the U.S. Geological Survey. Numbers are assigned in a downstream direction along the main stream, and stations on tributaries between main-stream stations are numbered in the order they enter the main stream. A similar order is followed on other ranks of tributaries. The complete 8 -digit number, such as 13202000 , which is used for the station "Boise River near Boise" includes the part number "13," indicating that the Boise River is in the Snake River Basin, plus a 6-digit station number.

\section{GEOLOGIC FRAMEWORK}

Rock units ranging in age from Cretaceous to Holocene underlie the Boise River valley. The surface distribution of the rock units is shown in figure 2 and has been generalized from the work of Nace, West, and Mower (1957), and Savage (1958). The following discussion concerns only those formations extensively exposed in the report area.

The oldest formation exposed is the Idaho batholith of Cretaceous age. It is composed of gray quartz monzonite and granodiorite, with associated schists and gneisses. The Idaho batholith probably underlies the entire study area at depth and forms a troughlike basin in which younger rocks were deposited.

The Glenns Ferry Formation of the Idaho Group laps onto and unconformably overlies the Idaho batholith. The Glenns Ferry Formation is probably of late Pliocene and early Pleistocene age and is composed mainly of unconsolidated, complexly intertongued continental deposits of clay, silt, sand, and fine gravel. It also contains some volcanic ash and local lava flows of olivine basalt. Total thickness of the formation in the study area is about $2,000 \mathrm{ft}(600 \mathrm{~m})$. As indicated by drillers' logs of wells, the formation underlies a large part of the study area at shallow depths.

Overlying the Glenns Ferry Formation is a sequence of unconsolidated silt, sand, and well-sorted gravel beds of Pleistocene age, herein referred to informally as the older terrace gravel. The gravel contains crystalline pebbles and cobbles of the Idaho batholith but does not contain basalt debris from the Snake River Group. Exposures are characterized by cut-and-fill channels, inclined bedding, and cross bedding. These deposits have been eroded by floodwaters and 
form prominent terraces. The total thickness of this unit is about $150 \mathrm{ft}(45 \mathrm{~m})$.

Flows of vesicular olivine basalt belonging to the Snake River Group crop out southeast of Boise and north of Caldwe11. The age of these basalts ranges from Pleistocene to Holocene. The sources of the basalt flows are mostly outside the study area. Maximum thickness of the flows in the study area is about $300 \mathrm{ft}(90 \mathrm{~m})$.

Several lower river terraces occurring north and south of the Boise River are composed of unconsolidated clay, silt, sand, and well-sorted gravel that contains pebbles and cobbles $O F$ the Idaho batholith and of the Snake River Group. These sedimentary deposits are Pleistocene and Holocene in age and are herein referred to informally as the younger terrace grave1. The maximum thickness of this unit is about $100 \mathrm{ft}(30 \mathrm{~m})$.

The youngest rock unit exposed in the study area is the unconsolidated alluvium of Holocene age. It is composed of silt, sand, and coarse, well-sorted gravel and comprises the flood plains of the Boise River and some of the larger tributaries where it directly overlies the Glenns Ferry Formation. Maximum thickness of the alluvium is about 50 ft $(15 \mathrm{~m})$. Most of the area is covered with a soil mantle, which is as much as $20 \mathrm{ft}(6 \mathrm{~m})$ thick in a few areas.

\section{GENERAL HYDROLOGY ALONG BOISE RIVER}

\section{Ground Water}

The aquifers underlying the study area can be categorized as either deep or shallow. The only deep aquifer of concern is the Glenns Ferry Formation. Because very little is known about the hydrology of the Glenns Ferry Formation, and because the Boise River is in direct hydraulic connection with the shallow aquifers only, this report will deal exclusively with the hydrology of the shallow aquifers.

The shallow aquifers are the older terrace gravel, basalts of the Snake River Group, the younger terrace gravel, and the alluvium of Holocene age. Although each has individual hydraulic characteristics (Nace and others, $1957, \mathrm{p} .21-22$ ), the aquifers act as a single hydrologic unit and, for purposes of this report, they are treated as such. The areal distribution of the shallow aquifers is shown in figure 2 .

The materials composing the four shallow aquifers lie on the eroded surface of the Glenns Ferry Formation, and 
ground water in them occurs under water-table conditions in most places. However, artesian pressures exist at depth at several locations in the valley.

Present1y, most of the recharge to the shallow aquifers results from the downward percolation of precipitation and of irrigation water applied between about April 15 and October 15 (the irrigation season). Other sources of recharge include the leakage from irrigation canals and laterals and the downward percolation of domestic waste water from septic tanks. Other lesser amounts of recharge are probably supplied by the upward leakage of water from the underlying Glenns Ferry Formation in areas of artesian pressure and by the natural influx of ground water from outside the study area.

The general direction of ground-water movement in the study area can be deduced from the water-level map (fig. 5). Movement of the water is downgradient at right angles to the contours. Throughout most of the area, ground water flows to the northwest at a gradient of about $12 \mathrm{ft} / \mathrm{mi}(23 \mathrm{~m} / \mathrm{km})$, or a slope of 0.0023 . Some of the shallow we11s in the study area tap local, weak artesian zones, but do not flow at the ground surface. Such wells are often hard to distinguish from nearby water-table we11s strictly on the basis of water levels. It is likely that some of the wells alternate between water-table and artesian conditions as water levels change with time.

The widespread application of irrigation water, which began in 1863, has significantly altered the ground-water regime. Under pre-irrigation conditions, the principal sources of recharge to ground water were seepage from the Boise River and from precipitation. Evidence of limited recharge from precipitation is provided by the layers of caliche, common in many desert areas of the west, which exist a few feet underneath the surface in many parts of Boise River valley. This feature is formed by calcium carbonate and other salts that were leached from the soil and redeposited at the depths to which soil water usually penetrated. The water table under the river terraces at the time of caliche formation was very deep, possibly well below the river level on the south side.

After irrigation began, however, water levels on both sides of the river rose steadily; the rise at some places was as much as $140 \mathrm{ft}(43 \mathrm{~m})$ between 1912 and 1921 (Nace, West, and Mower, 1957, p. 10). When ground-water leve1s exceeded river levels, the river began to receive return flows from the ground-water reservoirs. Annual water-level highs now occur in early fall, near the end of the irrigation season, and annual lows occur in the spring, just prior to 
the beginning of the irrigation season (fig. 6). Dion $(1972, \mathrm{p} .27)$ reported an average water-level rise of 4.3 ft $(1.3 \mathrm{~m})$ between March and October 1970 .

The Geological Survey has monitored water levels in shallow observation wells throughout the Boise River valley. Hydrographs of these wells, two of which are shown in figure 6, show no definite long-term trend in water levels since the mid-1950's, and other data indicate that there has been little net change in some areas since the $1930^{\prime} \mathrm{s}$. The rise of water levels has been controlled in many areas of the valley by construction of an extensive system of drainage canals and ditches and by pumping from wells.

The aquifer discharges rather uniform flows continuously to the Boise River through a system of tributaries, drains, aida ditches. The amount of water in storage in the aquifer, as well as the discharge from it, increases and decreases with the rise and fall of the water table. Most winters, practically all of the inflow to the Boise River between Lucky Peak Lake and the mouth is ground-water discharge. Overland flow from precipitation below Lucky Peak Lake is only a few tens of thousands of acre-ft per year. The discharge of ground water from the aquifers during the nonirrigation season averages about 300,000 acre-ft $\left(0.7 \mathrm{~km}^{3}\right)$, which, by comparison, is about equivalent to the usable storage in Lucky Peak Lake or Arrowrock Reservoir. The total groundwater storage that has accumulated in the aquifer since irrigation began is, of course, many times greater.

According to samples collected and analyzed by the U.S. Geological Survey, as reported by Nace, West, and Mower (1957) and by Dion (1972), ground water in the shallow aquifers in the vicinity of Boise River is of generally good quality and suitable for most purposes (table 1). Concentrations of most constituents analyzed are within the drinking water standards recommended by the U.S. Public Health Service (1962). However, the dissolved-solids concentration (as estimated from specific-conductance values) in practically one-third of the nearly 300 samples from wells exceeded the recommended maximum of $500 \mathrm{mg} / 1$ (milligrams per liter). Water from wells is usually hard enough to make water softeners desirable, and iron is present in a few areas. Water samples from 29 silallow wells in highly urbanized areas were collected in 1970 and tested for fecal coliform bacteria. A11 of these tests were negative. Generally, Dion (1972) found that there appears to be no definite areal pattern with regard to the distribution of dissolved minerals in the shallow ground waters of the area. 

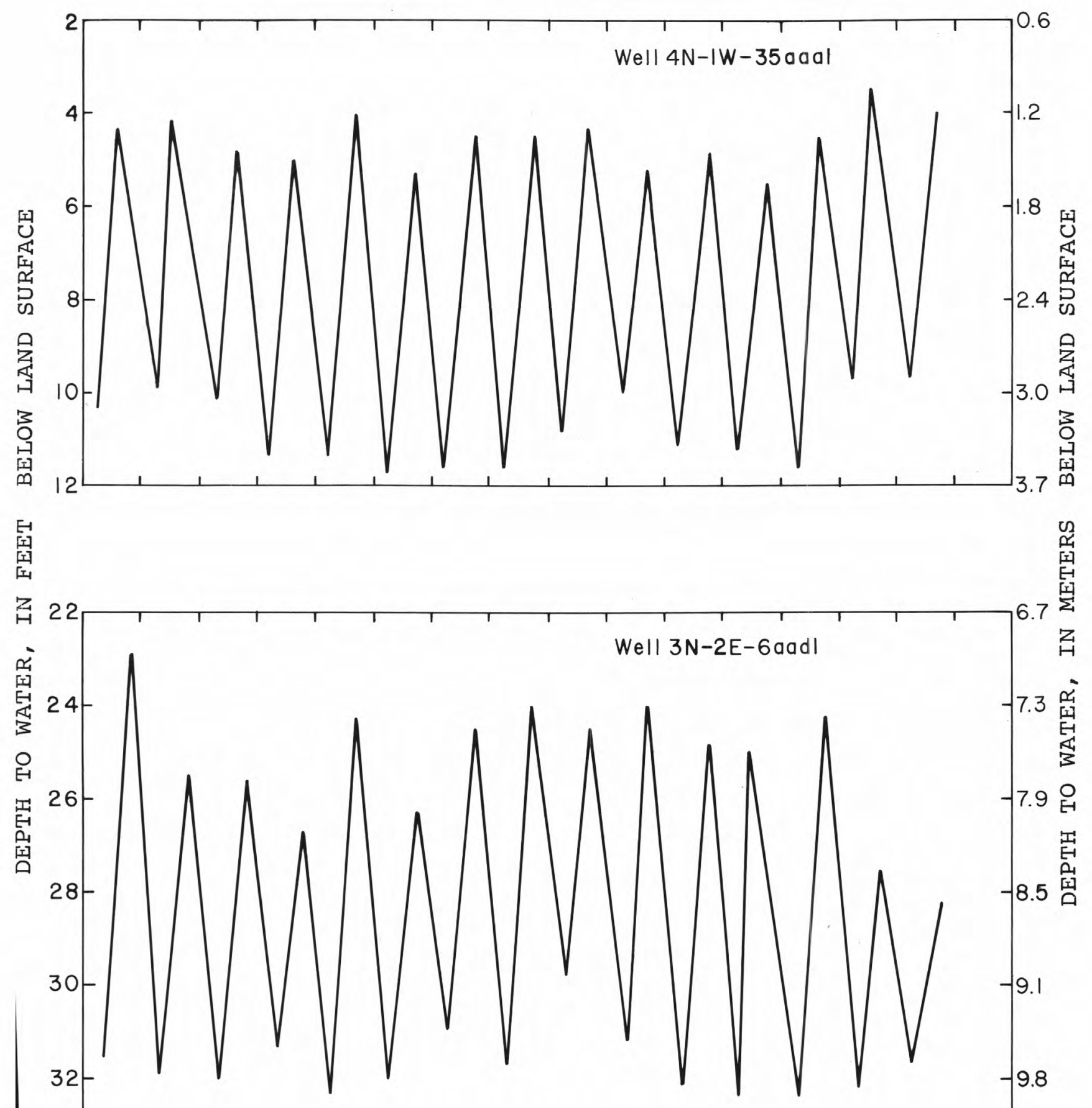

$34 \begin{array}{lllllllllll}1 & 1 & 1 & 1 & 1 & 1 & 1 & 1 & 1 & 1 & 1 \\ 1956 & 1958 & 1960 & 1962 & 1964 & 1966 & 1968 & 1970\end{array}$ GURE 6.--Hydrographs of selected observation wells showing seasonal water-level fluctuations (locations of wells shown in fig. 5). 
TABLE 1

Summary of chemical analyses for wells sampled in 1970 (From Dion, 1972)

\begin{tabular}{|c|c|c|c|c|}
\hline \multirow[b]{2}{*}{ Parameter } & \multirow{2}{*}{$\begin{array}{l}\text { Number } \\
\text { of } \\
\text { Samples }\end{array}$} & \multicolumn{2}{|c|}{ Range } & \multirow[b]{2}{*}{ Median } \\
\hline & & Low & High & \\
\hline Temperature $\left({ }^{\circ} \mathrm{C}\right)$ & 177 & 11.4 & 18.2 & 14.0 \\
\hline $\begin{array}{l}\text { Specific conductance } \\
\left(\text { micromhos at } 25^{\circ} \mathrm{C}\right)\end{array}$ & 191 & 104 & 1,210 & 596 \\
\hline Chloride (mg/1) & 191 & 0 & 63 & 16 \\
\hline Nitrate (mg/1) & 188 & 0 & 58 & 12 \\
\hline Phosphate (mg/1) & 80 & 0 & 1.8 & .24 \\
\hline
\end{tabular}


Discharge from the shallow aquifer occurs as (1) flow contributed to surface streams, in particular the Boise River, Indian Creek, Dixie Slough, Mason Creek, Sand Run Gulch, and Tenmile Creek; (2) evapotranspiration in areas where the water table is at or near land surface; and (3) flow from seeps and a few springs in the study area. Artificial discharge is effected by manmade drains, by pumping for various beneficial water uses, and by flowing and pumped drainage wells.

Yields from wells open to the shallow aquifers are generally high. According to reports from well drillers, yields as large as 4,000 gal/min or $2501 / \mathrm{s}$ and specific capacities as large as 185 (gal/min)/ft or $38(1 / \mathrm{s}) / \mathrm{m}$ of drawdown are obtainable from the shallow aquifers. Nace, West, and Mower (1957, p. 55) reported transmissivity values of about 17,000 to $230,000 \mathrm{ft}^{2}$ per day or 1,600 to $21,000 \mathrm{~m}^{2}$ per day and coefficient of storage values of 0.004 to 0.23 for the sha11ow aquifers.

\section{Surface Water}

General

The characteristics of flow in the Boise River below Lucky Peak Lake are determined, to a large extent, by regulation and diversions. Active storage in the four major reservoirs in the basin totals about 1.2 million acre-ft $\left(1.45 \mathrm{~km}^{3}\right)$, and nearly 350,000 acres $\left(1,400 \mathrm{~km}^{2}\right)$ of 1 and in the basin are irrigated with water from the Boise River or by the pumping of ground water. Diversions from Boise River below Lucky Peak Lake for irrigation averaged about 1.8 million acre-ft $\left(2.2 \mathrm{~km}^{3}\right)$ per year for water years 1956-70. The average natural flow in the Boise River below Lucky Peak Lake for the same period would have been 2.05 million acre-ft $\left(2.5 \mathrm{~km}^{3}\right)$. Net consumptive use during the growing season on the irrigated land averages more than $2.0 \mathrm{ft}$ $(0.6 \mathrm{~m})$ of water (Dion, $1972, \mathrm{p}$. 11) or a total of about 700,000 acre-ft $\left(0.9 \mathrm{~km}^{3}\right)$. As described earlier, application of irrigation water in excess of consumptive use causes a major buildup of ground-water storage and a resulting increase in ground-water discharge, which also affects distribution of flow in the river.

Winter and spring runoff from the mountainous part of the basin upstream from Lucky Peak Lake, most of which is from snowmelt, is stored in the reservoirs for later use during the irrigation season. Reservoir gates are lowered and only minimal flows are released from Lucky Peak Lake until snow accumulation in the upper basin indicates that 
releases for flood control will be required or until releases are needed for irrigation (fig. 12). Reservoirs generally reach their maximum storage about June 30 . Storage is withdrawn for irrigation when demand exceeds natural inflow, usually from about July 1 to the end of the irrigation. season, about October 15 .

During seasons of no excess flow, only enough water is released at Lucky Peak Dam to fill demands. During wet years, however, large quantities of water above local needs are released, sometimes beginning in December and continuing through June, to provide storage space for flood waters. Excess watcr is rarely released from July to November. The irrigation season usually is from about April 15 to October 15, although the season is longer on some of the lower lands. Hydrographs of average monthly flows for the period 1956-70 and monthly flows for the dry year of 1961 and the wet year of 1965 for gaging stations on the Boise River and for the natural flows (inflows into the reservoirs) are shown in figure 7 .

The watermaster, who administers the irrigation water during the irrigation season, has divided the river below Lucky Peak Lake into three sections for water distribution purposes. Section 1 is from Diversion Dam at the head of the New York Canal to the Caldwell High-Line Canal about a mile southwest of Star (fig. 8). Section 2 is from the Caldwell High-Line Canal to the river bridge at Notus, where gaging station 13212500 is located. Section 3 is from the river bridge at Notus to the Snake River.

Enough water is delivered through Lucky Peak Dam, if available, to serve all canals in section 1 . The return flow to the Boise River from ground-water discharge is augmented in summer by considerable overland flow and subsurface flow from irrigation. Comparison of the watermaster's records from his annual reports (Musselman, written comm., 1971) and the measurements of November 17-18, 1971, show that summer flow in many of the ditches and drains for long periods is 50 percent or more larger than the winter flows that have been measured. Although some of this water returns to the river within section 1 , water is divided and measured by the watermaster according to the decrees. A considerable amount of the available stored water is needed to fill demands in this section. In section 2 , most of the water needed to fill diversion needs is provided by return flow, and very little release from Lucky Peak Lake is required. In section 3 , return flows fill all diversion needs, and there is nearly always surplus water in this subreach of the river. Stored water has been needed in section 3 only once since 1917, and that was during the extreme drought year of 1934 . 


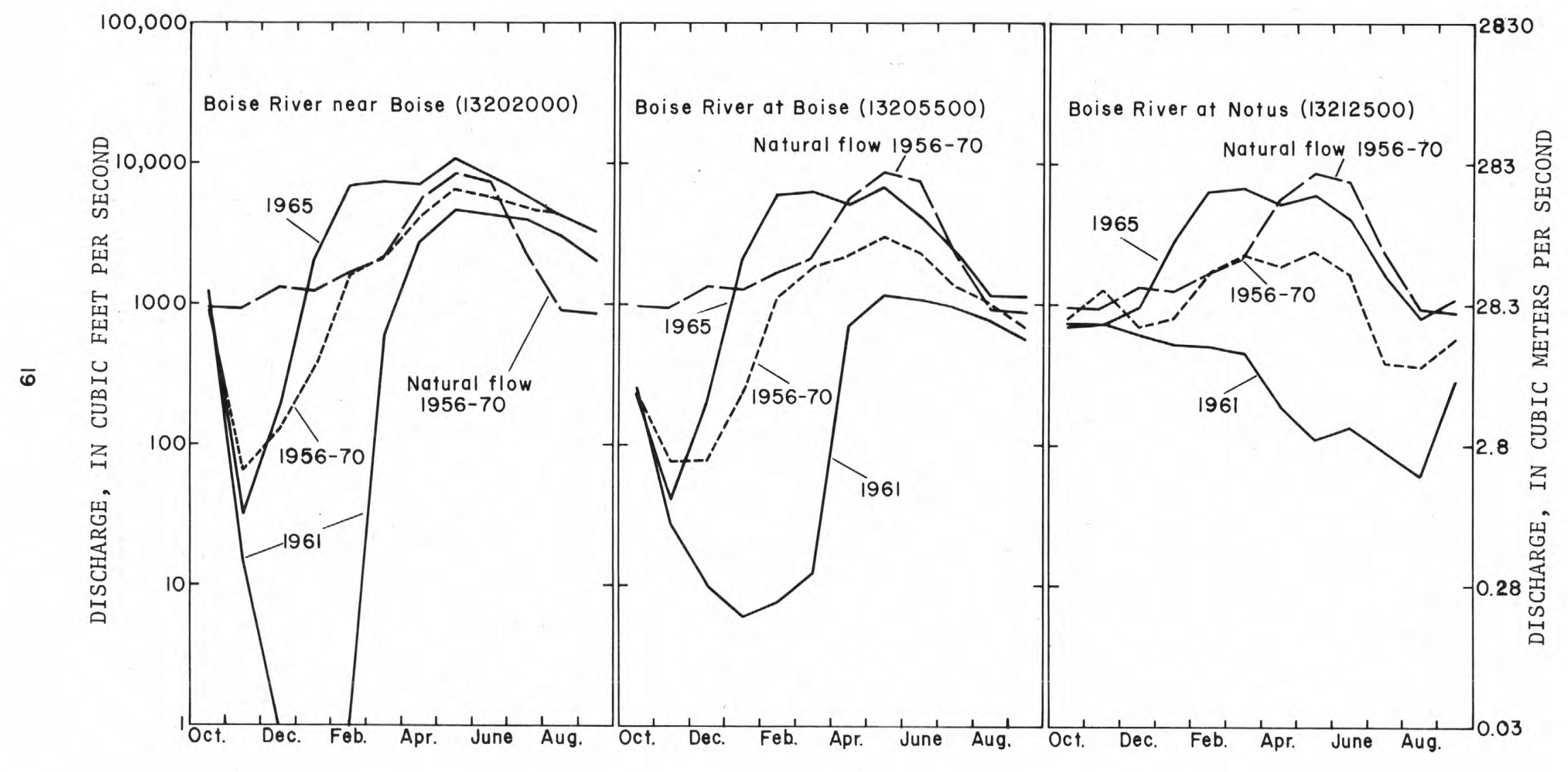

FIGURE 7.--Hydrographs of monthly streamflow of Boise River gaging stations for selected years. 
Storage and diversion of water for irrigation make the distribution of flow in the study reach during the irrigation season very different from the distribution of flow in the nonirrigation season. Releases from Lucky Peak Lake are always relatively large in the irrigation season, but diversions reduce the flow downstream so that flows often are relatively small at Notus and at Star, for example. However, during the nonirrigation season when natural flows are being stored, the situation is reversed. During this time, flows below Lucky Peak Lake are often very low, but relatively large flows occur in the lower part of the reach.

\section{Flow-Duration Characteristics}

The flow-duration curve (Searcy, 1959) provides a means of representing the flow characteristics at a gaging site. It shows the percentage of time during the base period that specified discharges were equaled or exceeded. Duration curves are shown in figures 9 and 10 for the three gaging stations Boise River near Boise, Boise River at Boise, and Boise River at Notus for water years 1956-70. The 1956-70 period was chosen because water year 1956 was the first complete year of operation for Lucky Peak Dam and Lake. Figure 9 is for the 6-month period October 1 to March 31; figure 10 is for the period April 1 to September 30. Because of numerous diversions and return flows and the degree of regulation on the Boise River below Lucky Peak Lake, the flow-duration curves presented in this report apply only to the gaging site for which the curve was prepared. Adjustments using diversion and return-flow data are necessary to make these curves applicable to other points.

Duration hydrographs are another presentation of duration characteristics. Duration hydrographs are presented in figures 11-14 for the natural flow into the reservoir system and for the three gaging stations below Lucky Peak Lake. For each day of the year, these figures show the highest, lowest, and median laily discharges for the gaging-station locations. Except for figure 11, they also show the daily discharges, which were exceeded 80 percent and 20 percent of the time during the indicated period of record. The period of record, October 1, 1952, to September 30, 1971, includes a11 of the record since Lucky Peak Dam was completed, plus the 1953 and 1954 water years which were included because the computer program used to prepare these hydrographs required 19 years of complete record. The 2 years, 1953 and 1954 , were slightly above average and some winter releases were made from Arrowrock Reservoir, but peaks were nominal and would likely have been lower if Lucky Peak Lake had been operative. Inclusion of these 2 years does not adversely affect the curves shown. 


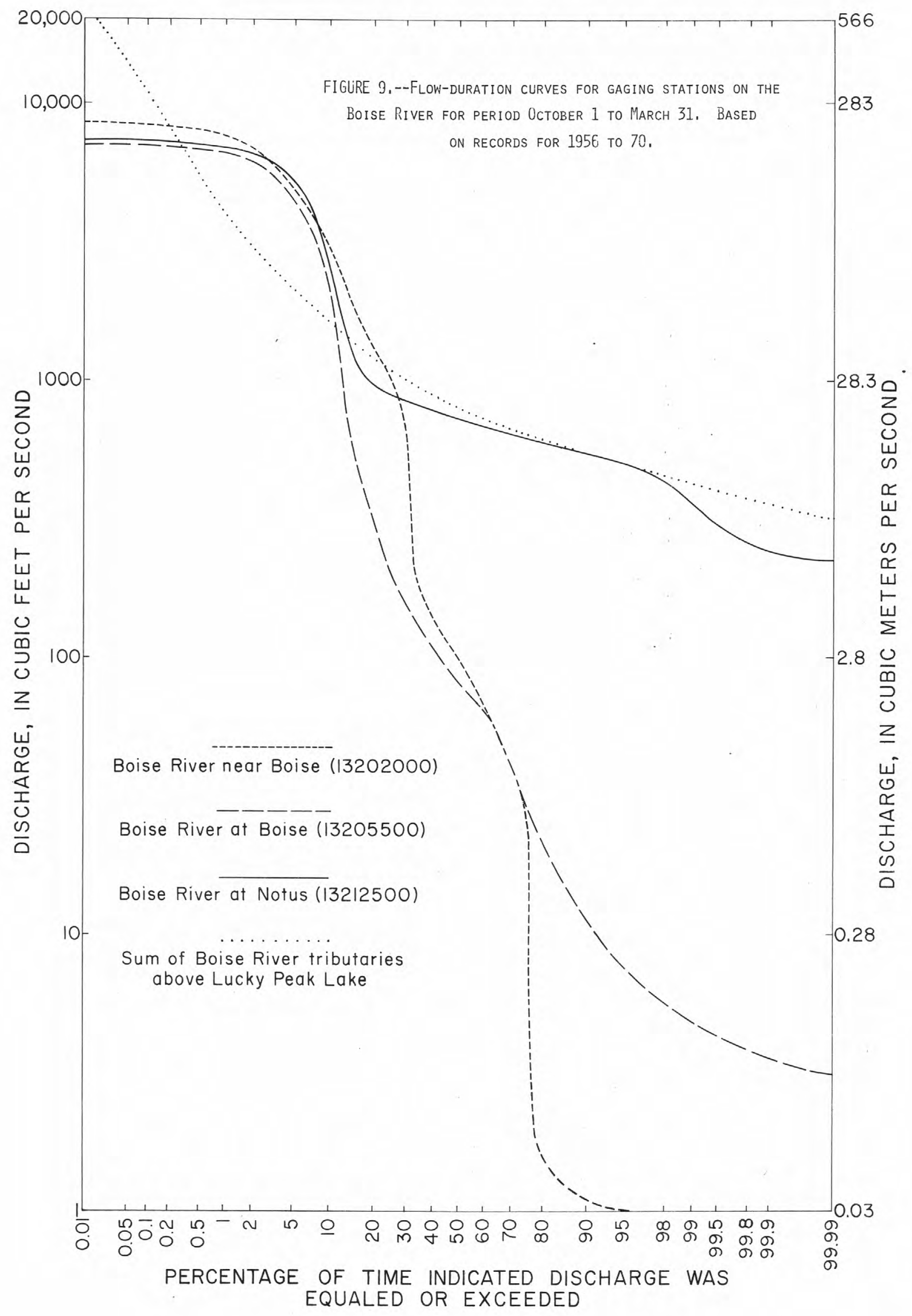




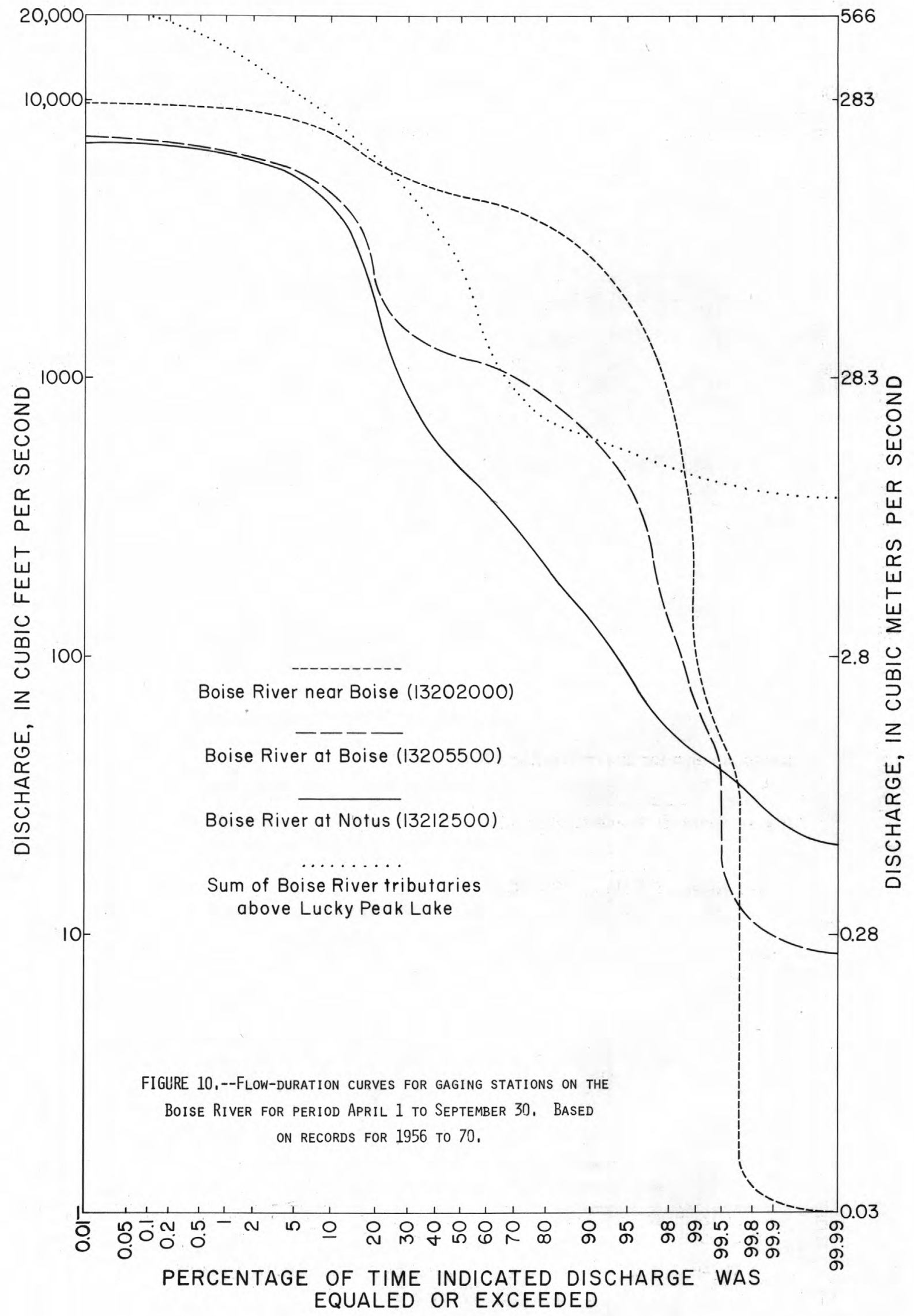




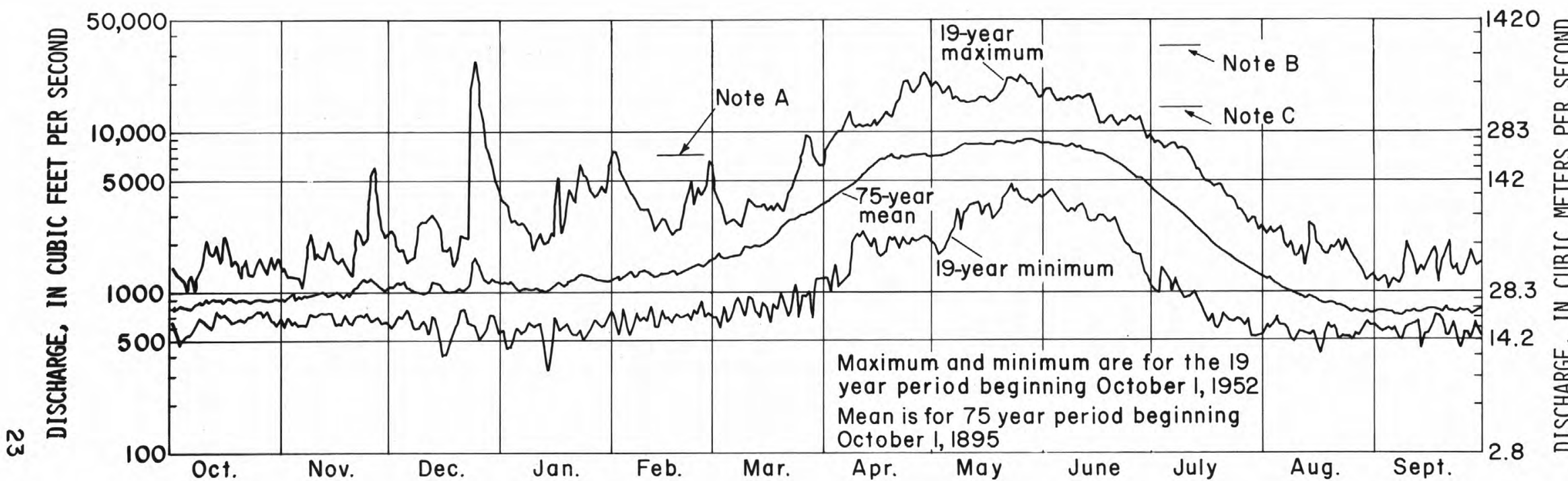

Note A: Maximum discharge at Boise River at Boise gaging station since completion of Lucky Peak Dam was 7240 cubic feet per second (205 cubic meters per second) May 22, 1965.

Note CilOO-year flood at Boise River at Boise gaging station with existing regulation and diversion, 15,000 cubic feet per second ( 425 cubic meters per second).

Note B: 100-year flood at Boise River at Boise gaging station assuming no regulation or diversion upstream, 36,000 cubic feet per second ( 1020 cubic meters per second).

FIGURE 11,--DURATION HYDROGRAPH OF NATURAL INFLOW TO RESERVOIRS IN BOISE RiVER BASIN (based on DATA FURnished by Boise River Watermaster), 


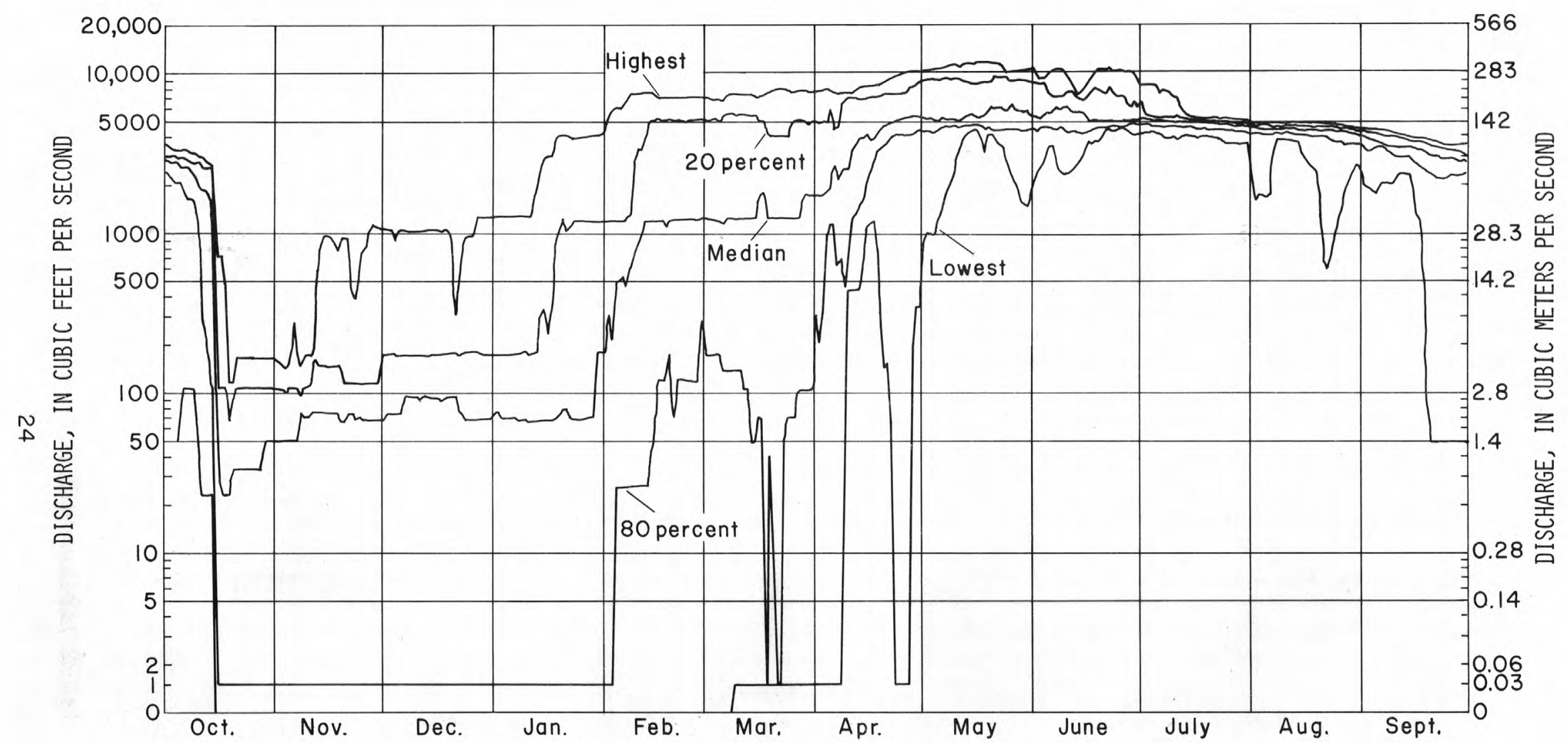

Figure 12,--Duration hydrograph, Boise River near Boise, Idaho, 19-Year period beginning October $1,1952$. 


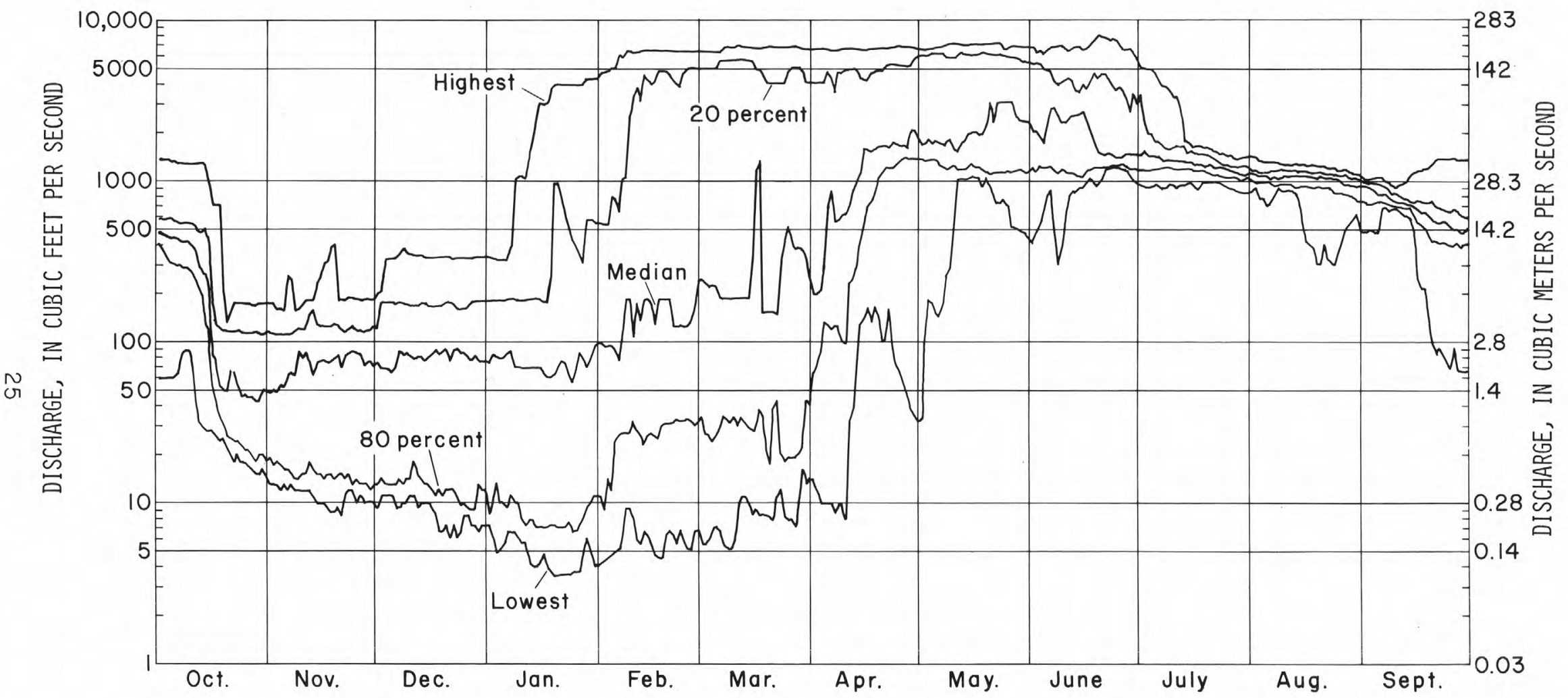

FigliRe 15,--Duration hydrograph, Boise River at boise, Idaho, 19-year Period beginning OCTOBeR 1 , 1952. 


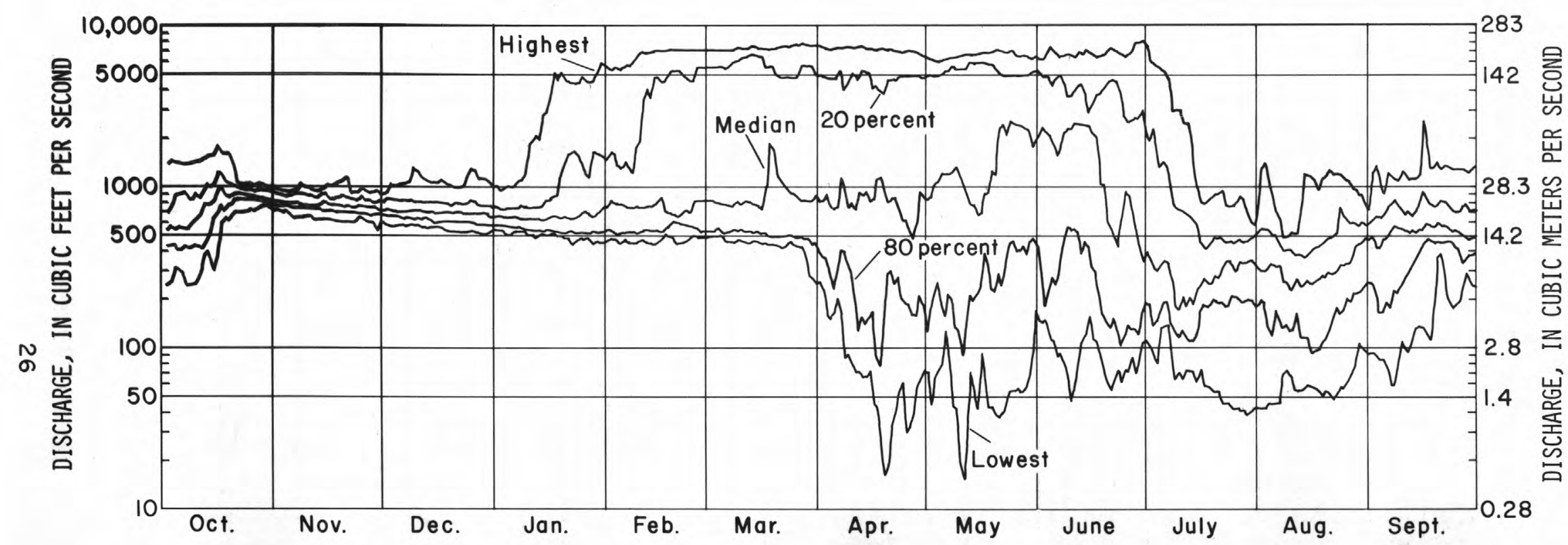

FiguRE 14,--Duration hydrograph, Boise River at Notus, Idaho, 19-year period BEgINNING OCTOBER $1 ; 1952$. 
The duration curves (fig. 9) show the magnitude of increase of streamflow in winter from Lucky Peak Lake downstream. During the 6-month period October 1 to March 31 , streamflow at gaging stations near Boise, at Boise, and at Notus equaled or exceeded about $1 \mathrm{ft}^{3} / \mathrm{s}\left(0.03 \mathrm{~m}^{3} / \mathrm{s}\right), 11 \mathrm{ft}^{3} / \mathrm{s}$ $\left(0.31 \mathrm{~m}^{3} / \mathrm{s}\right)$, and $550 \mathrm{ft}^{3} / \mathrm{s}\left(15.6 \mathrm{~m}^{3} / \mathrm{s}\right)$, respective1y, 90 percent of the time. Return flows maintained the discharge at Notus above $400 \mathrm{ft}^{3} / \mathrm{s}\left(11.3 \mathrm{~m}^{3} / \mathrm{s}\right) 98$ percent of the time (fig. 9). The very low flows at the gaging station near Boise occur when gates are lowered or closed at Lucky Peak Dam and water is being stored in upstream reservoirs.

The duration curves for the summer period (fig. 10) April 1 to September 30 show different characteristics. Flows at upstream stations are considerably higher than at downstream stations because of irrigation diversions. Streamflow at the gaging stations near Boise, at Boise, and at Notus equaled or exceeded about $2,800 \mathrm{ft}^{3} / \mathrm{s}\left(79 \mathrm{~m}^{3} / \mathrm{s}\right), 620$ $\mathrm{ft}^{3} / \mathrm{s}\left(18 \mathrm{~m}^{3} / \mathrm{s}\right)$, and $130 \mathrm{ft}^{3} / \mathrm{s}\left(3.7 \mathrm{~m}^{3} / \mathrm{s}\right)$, respectively, 90 percent of the time. Releases from Lucky Peak Lake maintained the flow at the gaging station near Boise above $800 \mathrm{ft}^{3} / \mathrm{s}$ ( 23 $\mathrm{m}^{3} / \mathrm{s}$ ) 98 percent of the time (fig. 10). During the summer, flow at the downstream stations exceeded the flow at

the upstream stations only for a brief period early in April before irrigation diversions began.

According to the Department of the Army, Walla Walla District, Corps of Engineers (written comm., 1974), the records of the lowest flows on which the duration hydrographs and duration curves for Boise River near Boise were based are not representative of low flows expected in the future. The first few years of operation of outflow through Lucky Peak Dam required more extensive closures for repairs to the outlet structure than are anticipated in the future. In the future, complete closures (flows near zero) are expected to last from a week to 10 days while the conduit and outlet works are inspected. About once every 10 years, the closure will probably last as much as 6 weeks while repairs and other maintenance activities are accomplished. During the remainder of the filling period in the nonirrigation seasons, minimum flows of 20 to $200 \mathrm{ft}^{3} / \mathrm{s}\left(0.6\right.$ to $\left.6 \mathrm{~m}^{3} / \mathrm{s}\right)$ will be passing Diversion Dam for maintenance of the fishery in the upper end of the study reach.

For comparative purposes, the duration curves for the combined discharge for gaging stations Boise River near Twin Springs (13185000), South Fork Boise River near Featherville (13186000), and Mores Creek above Robie Creek (13200000) are shown by the dotted lines on figures 9 and 10 . These sites are $34 \mathrm{mi}(55 \mathrm{~km}), 74 \mathrm{mi}(116 \mathrm{~km})$, and $12 \mathrm{mi}(17 \mathrm{~km})$, respectively, above Lucky Peak Dam. The combined flow at these three sites is roughly 80 percent of the natural flow into the storage reservoirs above the gaging station 
near Boise (13202000). Comparison of these curves with the curves at sites below Lucky Peak Lake indicate how much regulation by the reservoirs and diversions has affected natural flow in the Boise River.

Differences in characteristics of the hydrographs at the several stations indicate the effects of regulation and diversions on the characteristics of the flow as it progresses through the reach. For example, comparison of the 19-year maximum of the natural flow (fig. 11) with the maximums below Lucky Peak Lake (figs. 12-14) shows that large reductions in maximum flows result from regulation and the diversions. Likewise, comparison of minimums shows the extreme reductions in low flows that result from gate closures and from diversions.

Records show that total inflow into the reservoir system exceeded $15,000 \mathrm{ft}^{3} / \mathrm{s}\left(425 \mathrm{~m}^{3} / \mathrm{s}\right)$ for 18 days in 1956 , 6 days in 1969,21 days in 1965, and 7 days in 1969. The maximum mean daily inflow was $28,000 \mathrm{ft}^{3} / \mathrm{s}\left(790 \mathrm{~m}^{3} / \mathrm{s}\right)$ on December 23, 1964. The maximum momentary discharge for the station at Boise during $1956-70$ was $7,240 \mathrm{ft}^{3} / \mathrm{s}\left(205 \mathrm{~m}^{3} / \mathrm{s}\right)$. These large reductions are evident from the duration hydrographs (figs. 11-14). The duration curves and duration hydrographs show that the periods of high flows are longer downstream from Lucky Peak Lake than in the upstream tributaries. The duration curves and hydrographs also show that regulation and diversions materially reduced the magnitude of the low flows at times during summer months. Flows into the reservoirs (fig. 11) have rarely been less than about $500 \mathrm{ft}^{3} / \mathrm{s}\left(14 \mathrm{~m}^{3} / \mathrm{s}\right)$, but flows less than $100 \mathrm{ft}^{3} / \mathrm{s}\left(2.8 \mathrm{~m}^{3} / \mathrm{s}\right)$ have occurred relatively often at all three gaging stations in the study reach, and flows have been less than $10 \mathrm{ft}^{3} / \mathrm{s}$ $\left(0.3 \mathrm{~m}^{3} / \mathrm{s}\right)$ relatively often at the gaging stations near Boise and at Boise.

\section{Characteristics of Low Flows}

The adequacy of streamflow to provide for municipal, industrial, and agriculture requirements, to maintain suitable conditions for fish, and to dispose of wastes is most critical during periods of low flow. The low-flow frequency curve provides a means of statistically evaluating the characteristics of low flows at a particular site. The curve shows the average discharges for a given number of consecutive days plotted against the recurrence interval, in years, in which the average discharges have not been exceeded.

Frequency curves of the 1-, 3-, 7-, 14-, 30-, and 60day mean low flows are shown in figures 15, 17, and 19 for 


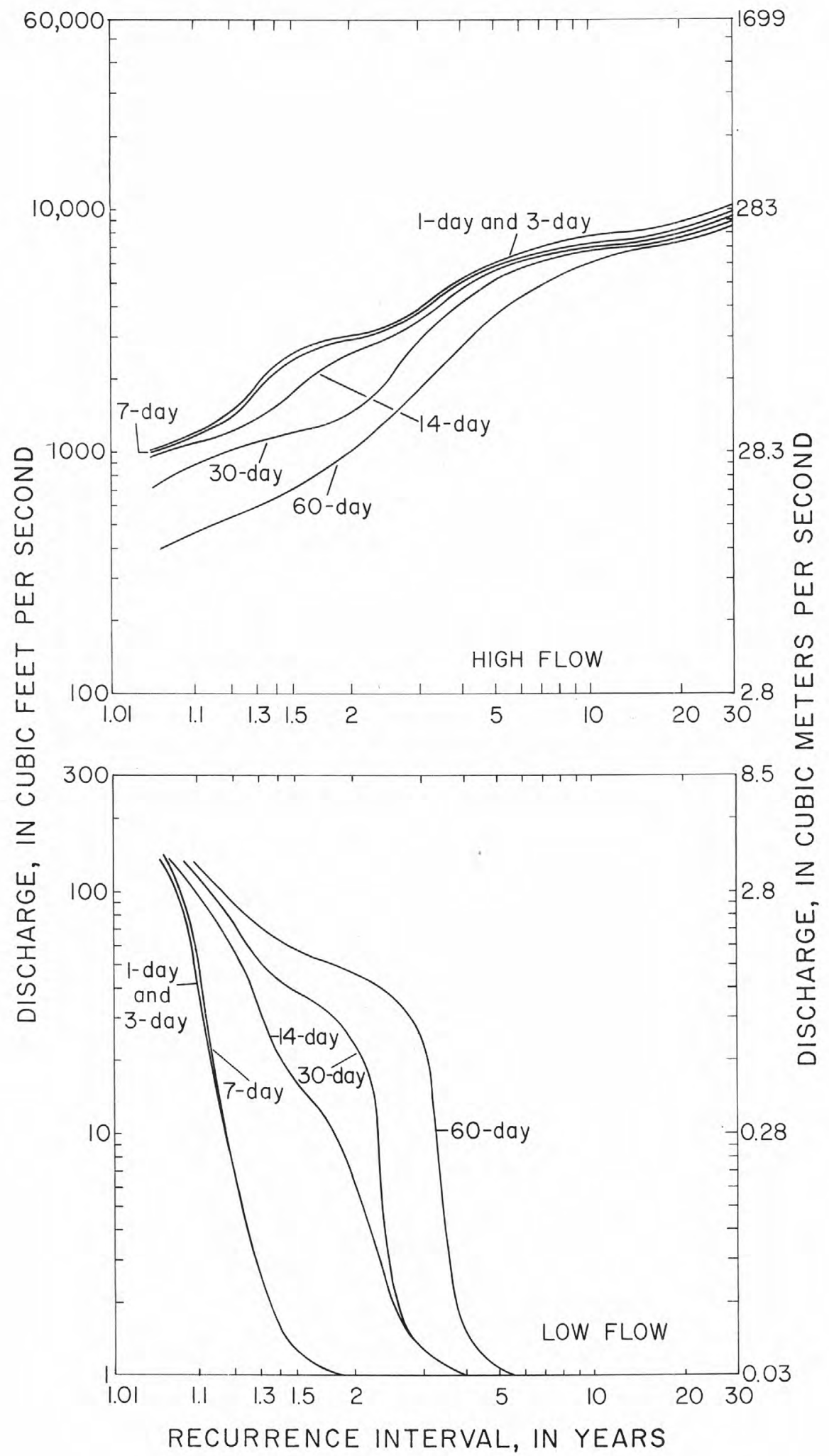

FIGURE 15,--HIGH-FLOW AND LOW-FLOW FREQUENCY CURVES, BOISE River near BoIse, 0ctober 1 to March 31, Based ON RECORDS FOR 1956 TO 70 , 


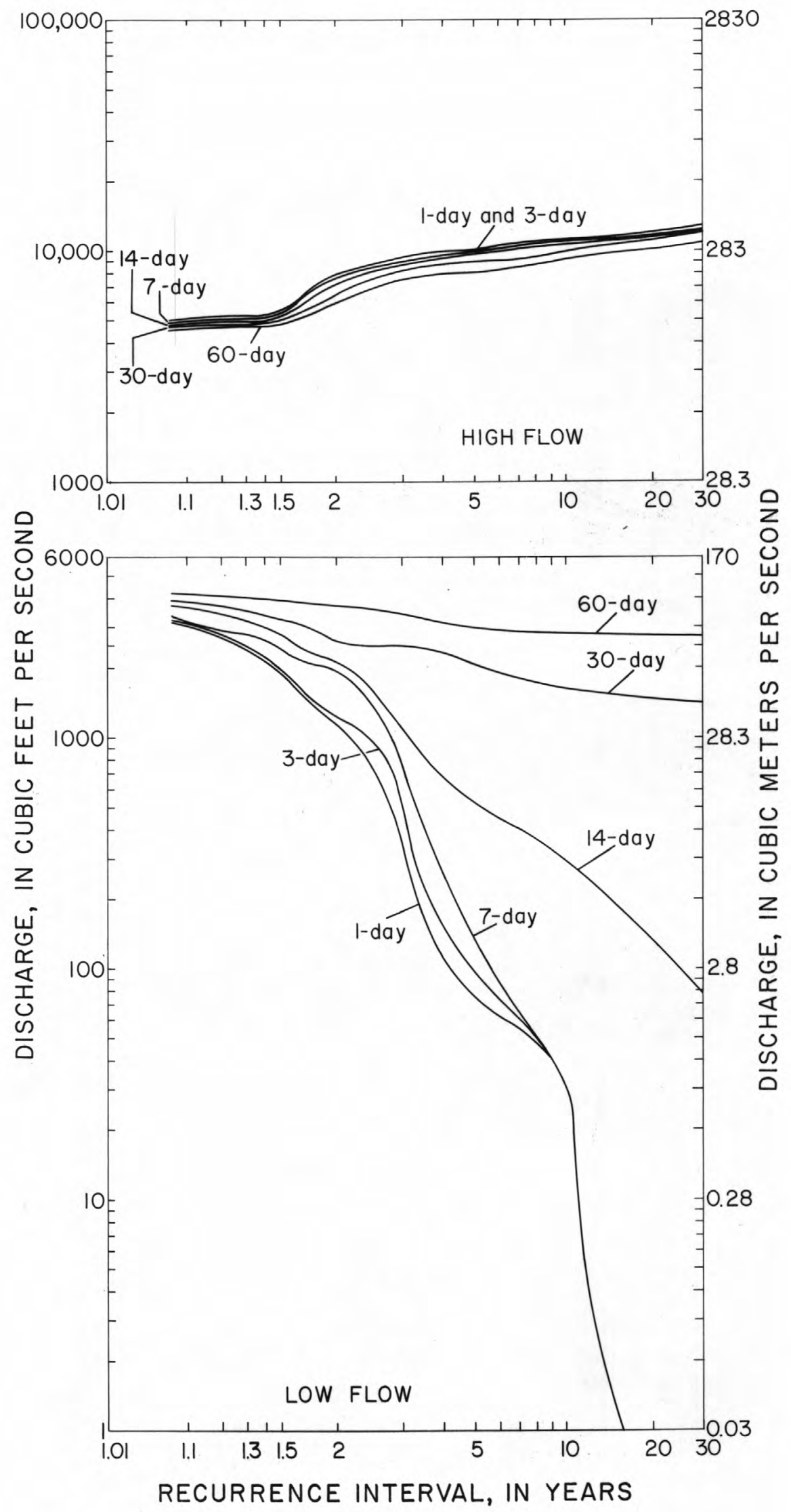

FIGURE 16,--HIGH-FLOW AND LOW-FLOW FREQUENCY CURVES, BOISE River near Boise, April 1 to September 30. Based ON RECORDS FOR 1956 TO 70. 


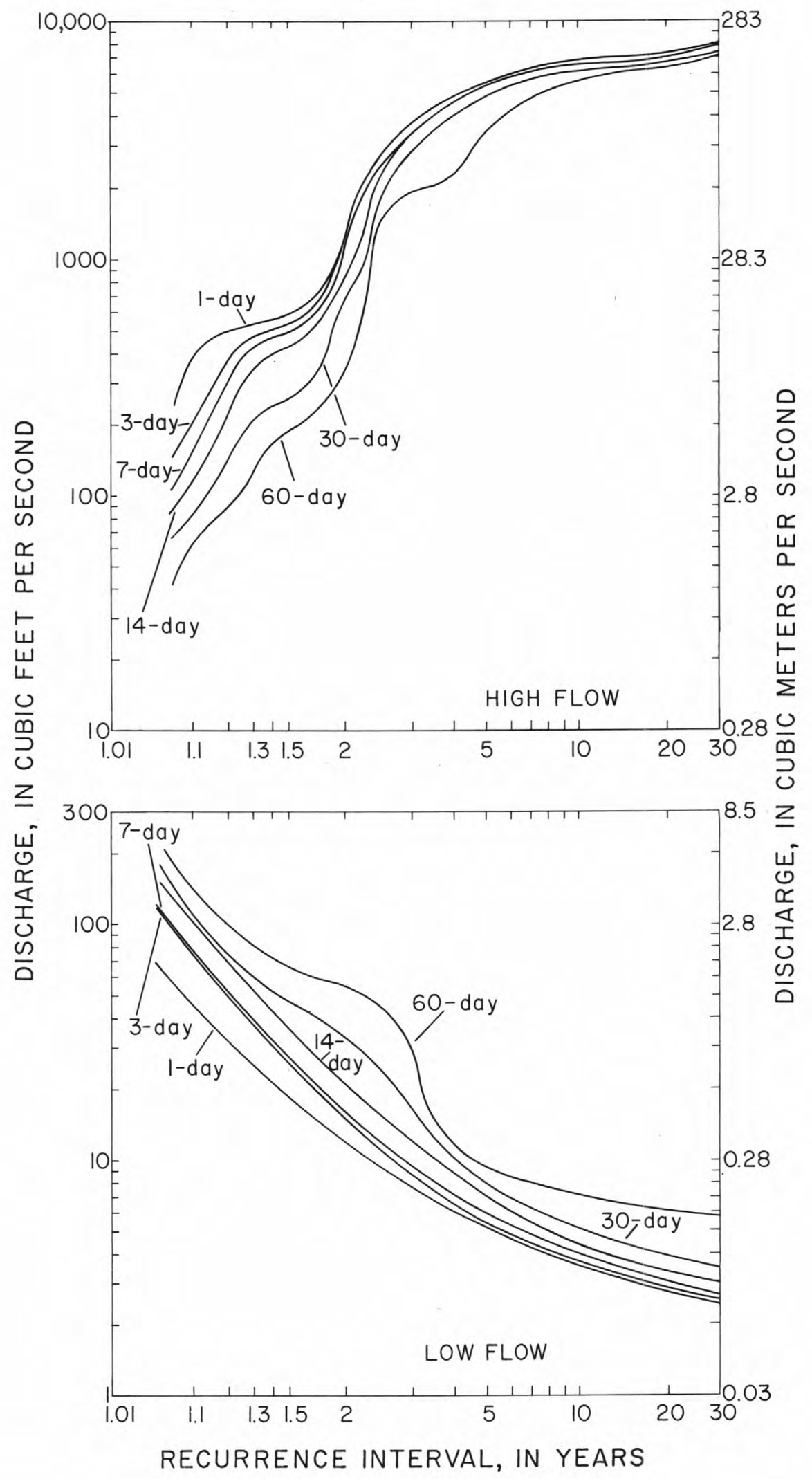

FIGURE 17,--High-FLOW AND LOW-FLOW FREQUENCY CURVES, BOISE River at Boise, October 1 to March 31. Based on RECORDS FOR 1956 TO 70. 


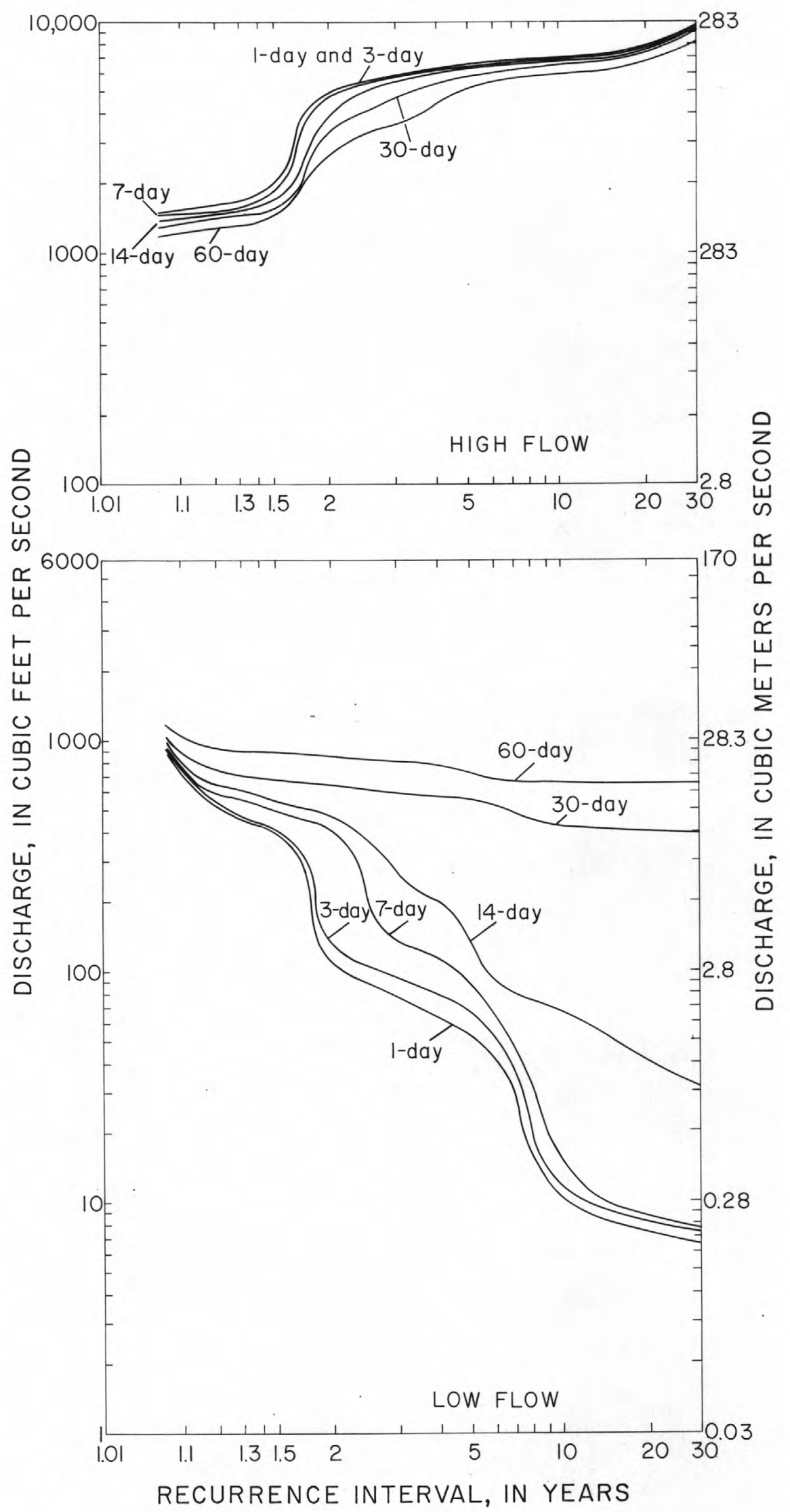

FIGURE 18,--HIGH-FLOW AND LOW-FLOW FREQUENCY CURVES, BOISE River at Boise, April 1 to September 30, Based on RECORDS FOR 1956 TO 70. 


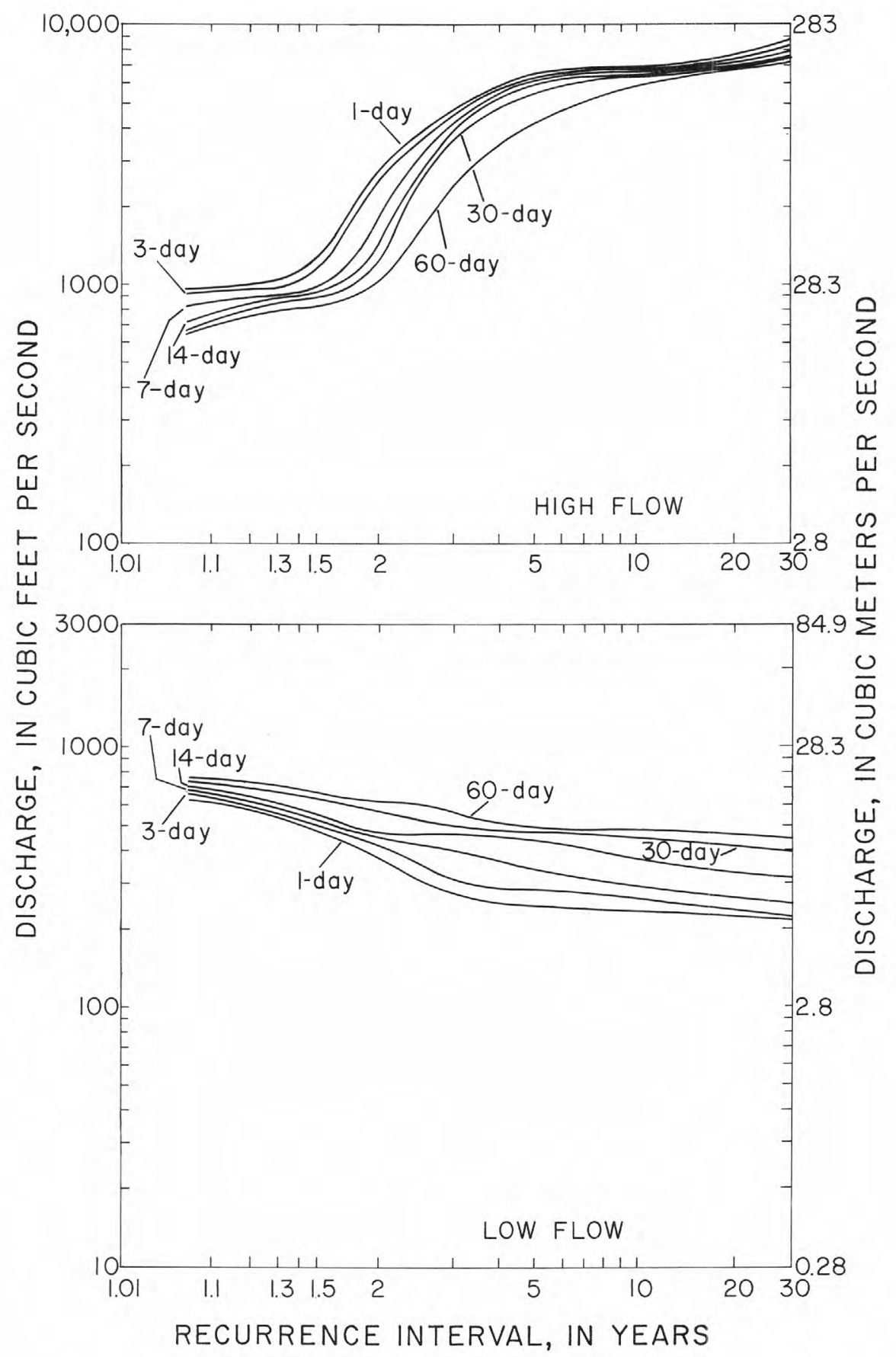

FIGURE 19,--HIGH-FLOW AND LOW-FLOW FREQUENCY CURVES, BOISE River at hotus, October 1 to March 31. Based on RECORDS FOR 1956 TO 70. 


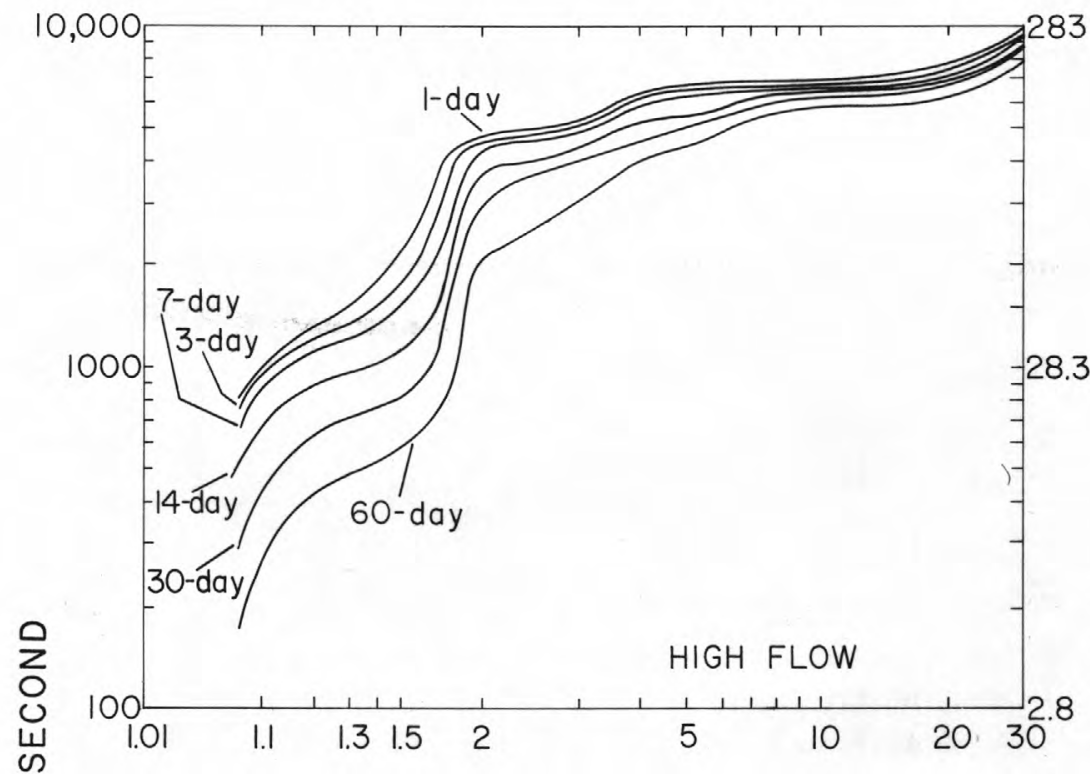

0
Z
U
w

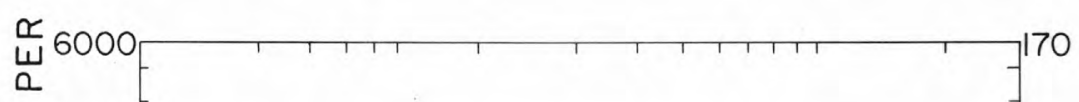

番

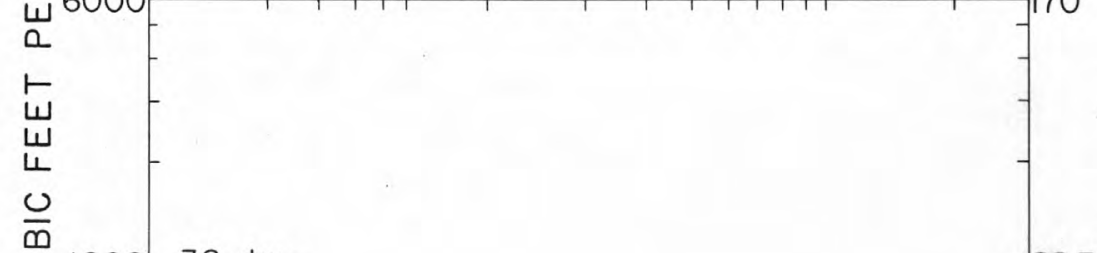

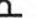

(n)

山

$\stackrel{5}{\Sigma}$

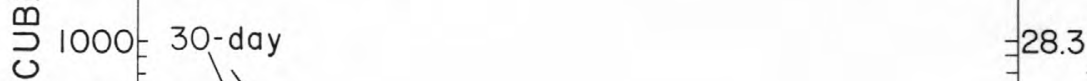

$\underline{z}$

U.

立
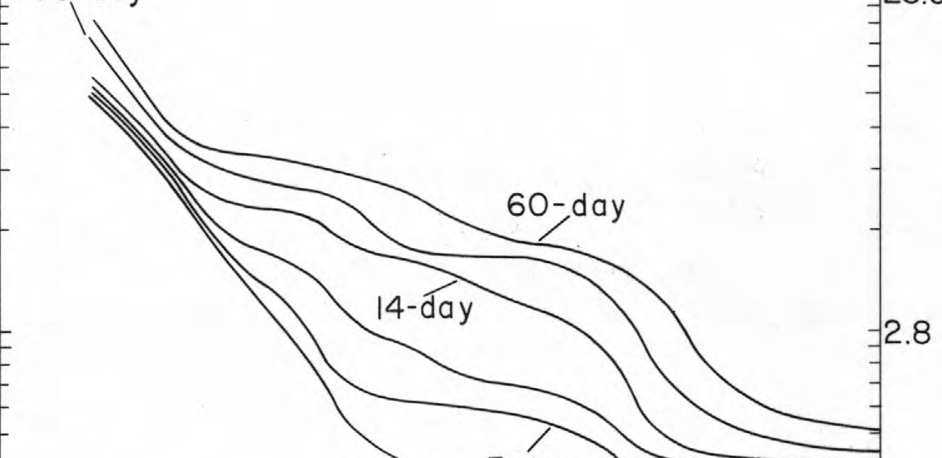

0
0
0
0
$z$
U.
0
0
$\frac{1}{1}$
0
0
0
0

LOW FLOW

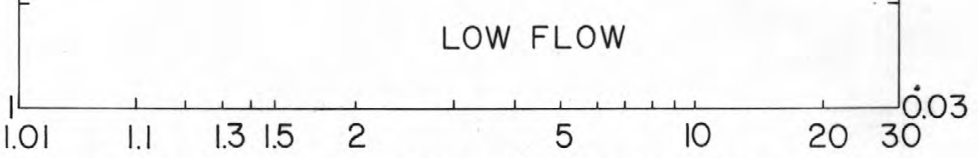

RECURRENCE INTERVAL, IN YEARS

FIGURE 20,--HIGH-FLOW AND LOW-FLOW FREQUENCY CURVES, BOISE River at Notus, April 1 to September 30. Based on RECORDS FOR 1956 TO 70 . 
October 1 to March 31 and in figures 16, 18, and 20 for April 1 to September 30 for each of the three gaging stations on the Boise River below Lucky Peak Dam. The curves are based on data for water years 1956-70. The curves are drawn through points reflecting recorded data and are not based on Log-Pearson or other statistical frequency distributions; that is, the curves are not smooth statistical plots but are irregular plots that represent actual recorded mean discharge at the frequencies shown.

October 1 to March 31.--The low-flow frequency curves for the station near Boise (fig. 15) have a steep slope because of regulation by Lucky Peak Dam immediately upstream from the station. Flows at the station averaged $1.0 \mathrm{ft}^{3} / \mathrm{s}$ $\left(0.03 \mathrm{~m}^{3} / \mathrm{s}\right)$ or less for 1,3 , and 7 consecutive days, 1 year in 2 years. That is, in 50 percent of the years, low flows have averaged $1.0 \mathrm{ft}^{3} / \mathrm{s}\left(0.03 \mathrm{~m}^{3} / \mathrm{s}\right)$ or 1 ess for at least 7 consecutive days. Flows have also averaged $1.0 \mathrm{ft}^{3} / \mathrm{s}\left(0.03 \mathrm{~m}^{3} / \mathrm{s}\right)$ or less once in about 4 years for 14 -day and 30-day periods, and have been $1.0 \mathrm{ft}^{3} / \mathrm{s}\left(0.03 \mathrm{~m}^{3} / \mathrm{s}\right)$ or less for 60 days once in about 6 years.

The curves for the station at Boise (fig. 17) show that low flows usually were significantly higher than at the station near Boise. This greater flow resulted from groundwater discharge between the gages during winter periods when the gates at Lucky Peak Dam were closed.

Low-flow frequency curves for the station at Notus (fig. 19) show that the low flows were always at least 200 $\mathrm{ft}^{3} / \mathrm{s}\left(5.7 \mathrm{~m}^{3} / \mathrm{s}\right)$ higher than discharges for corresponding time intervals and frequencies at the two upstream stations. Extreme low flows are not likely to occur in the winter at this station because practically none of the large groundwater discharge entering the river is diverted.

April 1 to September 30.--The frequency curves for the station near Boise (fig. 16) show that on the average, in 1 year in 16 years the flow has averaged less than $1 \mathrm{ft}^{3} / \mathrm{s}(0.03$ $\mathrm{m}^{3} / \mathrm{s}$ ) for at least 7 consecutive days. However, average flows for longer periods (14,30, and 60 consecutive days) and for recurrence intervals of less than 16 years are much higher.

The low-flow curves for the station at Boise (fig. 18) show higher discharges at the longer recurrence intervals and lower discharges at the shorter intervals than the corresponding curves for the station near Boise (fig. 16). Lowest flows at Boise in this 6-month period occur in the first few days of April before water generally is released from Lucky Peak Lake for irrigation. 
Average low flows at the station at Notus (fig. 20) were higher at long recurrence intervals and lower at short recurrence intervals than at the upstream stations. Minimum flows at this station occurred during the irrigation season (fig. 14) when irrigation demands were high and storage water in the reservoirs was being rationed. As shown in figure 20, summer flows at the Notus station have been below $100 \mathrm{ft}^{3} / \mathrm{s}$ $\left(2.8 \mathrm{~m}^{3} / \mathrm{s}\right)$ for as long as 60 days about 1 year in 11 years. During these extreme low-flow periods, flows were also extremely low below major diversions including Phyliis, Caldwell Highline, and Riverside canals.

\section{Characteristics of High Flows}

Below Lucky Peak Lake, extreme high flows on the Boise River have been materially reduced. The U.S. Army Corps of Engineers (written comm., 1967) estimated that the 100-year flood at the gaging station Boise River at Boise, with existing regulation and diversions, is $15,000 \mathrm{ft}^{3} / \mathrm{s} \cdot\left(425 \mathrm{~m}^{3} / \mathrm{s}\right)$. This was estimated from flows measured at the Boise River gaging station near Boise and from an analysis of inflow and irrigation diversions. The 100-year flood is defined as the flood that will be equaled or exceeded, on the average, once in 100 years, or has one chance in 100 of occurring in 1 year. Analyses based on the data of record show that the 100-year flood assuming no regulation or diversion would be about $36,000 \mathrm{ft}^{3} / \mathrm{s}$ $\left(1,020 \mathrm{~m}^{3} / \mathrm{s}\right)$. For comparison, these two 100 -year floods are plotted with the duration hydrographs of figure 11.

No large flood in Boise River has resulted from storms and resulting runoff below Lucky Peak Lake. Extremely high. flows from thunderstorm runoff have occurred in some of the minor tributaries below Lucky Peak Lake (Thomas, 1963). However, such floods are of short duration and volumes are so small that impact on flow in the main stem of the river is of little consequence.

Knowledge of high-flow characteristics is useful for the proper design of dams, bridges, culverts, highways, and levees, for the planning and use of flood plains and flood waters, and for the preparation of environmental-impact statements and related studies. High-flow frequency curves provide a means of representing the characteristics of high flows at a gaging site. These curves show the average discharges for a selected number of consecutive days that have been exceeded, on the average, once during the recurrence interval.

Frequency curves of the 1-, 3-, 7-, 14-, 30-, and 60day mean high flows are shown in figures 15,17 , and 19 for October 1 to March 31 and in figures 16, 18, and 20 for April 1 
to September 30 for each of the three gaging stations on the Boise River below Lucky Peak Dam. The curves are based on data for water years 1956-70. The high-flow frequency curves are drawn through plotting positions based on recorded data.

October 1 to March 31.--As shown in figures 15 and 17 , high flows at the station at Boise have been less than those at the station near Boise for almost all selected periods and frequencies, because water is diverted between these stations into the New York Canal to fill Lake Lowell prior to the general irrigation season. Nearly all high flows at the station at Notus were higher than those at the station at Boise for almost all selected periods and frequencies. This is due to the contribution of return flows and of ground-water discharge to the river and the lack of irrigation diversions between the two stations during this period.

April 1 to September 30.--Large reductions in high flows of the Boise River occur between the gages near Boise and at Boise as a result of the large diversions between the two stations, as is seen by a comparison of the high-flow frequency curves for these stations (figs. 16 and 18). Once in 30 years, on the average, the 1 -day high flow at the gaging station near Boise (fig. 16) would exceed about $13,000 \mathrm{ft}^{3} / \mathrm{s}\left(370 \mathrm{~m}^{3} / \mathrm{s}\right)$; the flow for the equivalent period and frequency at the gaging station at Boise (fig. 18) would exceed about $10,000 \mathrm{ft} / \mathrm{s}\left(280 \mathrm{~m}^{3} / \mathrm{s}\right)$. The decrease in flood potential during the irrigation season is much less between the gaging stations at Boise and at Notus than between the near Boise and at Boise stations because diversions in the reach downstream from Boise are smaller and because return flow compensates for much of the diverted water. However, high flows at the Notus station are less than those at the Boise stations for most recurrence intervals.

The decrease in peak flows below Lucky Peak Lake has been accompanied by aggradation of the river channel. For example, records at the gaging station Boise River at Notus show that $11,800 \mathrm{ft}^{3} / \mathrm{s}\left(335 \mathrm{~m}^{3} / \mathrm{s}\right)$ flowed in 1938 at the same stage as $8,000 \mathrm{ft}^{3} / \mathrm{s}\left(227 \mathrm{~m}^{3} / \mathrm{s}\right)$ flowed in 1972. Likewise, at the gaging station at Boise, $9,600 \mathrm{ft}^{3} / \mathrm{s}\left(270 \mathrm{~m}^{3} / \mathrm{s}\right)$ flowed in 1943 at the same stage as $7,700 \mathrm{ft}^{3} / \mathrm{s}\left(220 \mathrm{~m}^{3} / \mathrm{s}\right)$ flowed in 1972. Further study is desirable to show whether this aggradation is representative of aggradation in the study reach. If representative, similar figures of reduction in carrying cajacity probably apply at higher stages. In many places, bridges and other obstructions have noticeably restricted the channel and adjoining flood plains. 
HYDROLOGIC CONDITIONS ALONG BOISE RIVER

IN NOVEMBER, 1971

Ground Water

The complete closure of the gates, at Lucky Peak Dam during the period November 17-20, 1971, provided an opportunity for measuring the quantity of ground water entering the reach of Boise River extending from Lucky Peak Lake to the river's confluence with the Snake River. To supplement the surface-water data collected when the gates were closed at the dam, water levels in about 86 wells open to the shallow aquifers were measured at the same time streamflow measurements were being made along the Boise River and its tributaries. The results of the ground-water measurements are shown in figure 5 and in appendix A.

On November 18-19, 1971, ground-water levels in the vicinity of the Boise River were relatively high but had declined slightly from their seasonal peaks. Surface-water irrigation in Boise valley, the prime source of recharge to the shallow aquifers, had ceased by mid-October. Waterlevel contours ( $f i g .5$ ) indicate that ground water was discharging into the Boise River along most of the river's course below Lucky Peak Lake and into tributaries and major drainage channels.

The quality of water in the shallow aquifers was not sampled in November 1971 as part of this study, but it is reasonable to assume that its quality was generally the same as determined in 1970 (table 1).

\section{Surface Water}

Discharge measurements were made along the Boise River and at several tributaries, drains, canals, sloughs, and bypasses in the Boise River valley on November 18-19, 1971. The results obtained reflect a normal, stabilized return flow, practically all of which is from the ground-water aquifer to the Boise River during the early post-irrigation season.

The diversions for irrigation in the Boise River canals for 1971 totaled about 5 percent above the average for the 15-year period 1956-70. Diversions from Boise River ended on October 15, 1971, and the outflow from Lucky Peak Lake was reduced from about $2,400 \mathrm{ft}^{3} / \mathrm{s}\left(68 \mathrm{~m}^{3} / \mathrm{s}\right)$ to $110 \mathrm{ft}^{3} / \mathrm{s}$ $\left(3.1 \mathrm{~m}^{3} / \mathrm{s}\right)$. The mean daily flow of the Boise River at the gaging station near Boise and the precipitation at the Boise 
Municipal Airport for the period immediately preceding the measurements are as follows:

\begin{tabular}{lccc}
$\begin{array}{c}\text { Date } \\
(1971)\end{array}$ & $\begin{array}{c}\text { Discharge of Boise } \\
\text { River near Boise } \\
\left(\mathrm{ft}^{3} / \mathrm{s}\right)\end{array}$ & $\begin{array}{c}\text { Date } \\
(1971)\end{array}$ & $\begin{array}{c}\text { Precipitation at Boise } \\
\text { Municipal Airport } \\
\text { (inches) }\end{array}$ \\
\hline Nov. $11-12$ & 54 & Nov. 13 & 0.36 \\
Nov. 13 & 29 & Nov. 18 & .01 \\
Nov. 14 & 2.8 & & \\
Nov. 15 & 2.4 & & \\
Nov. $16-17$ & 2.3 & & \\
\hline
\end{tabular}

Because of the low antecedent flows noted above, changes in bank storage on November 18-19 were probably insignificant.

The flow in the channel of the Boise River was measured at 16 sites, including those at the three gaging stations. In addition, 20 measurements of flow were obtained in drainage channels that discharge into the Boise River or parallel it. The results of the measurements are summarized in table 2 and in appendix $B$, and are presented pictorially in figures 8 and 21. Several measurements of drainage channels of less than $10 \mathrm{ft}^{3} / \mathrm{s}\left(0.3 \mathrm{~m}^{3} / \mathrm{s}\right)$ are not 1 isted individually in the tables. More detail of the smaller flows is published in an annual report (U.S. Geol. Survey, 1973).

The measurements show that the total flow in the river system increased from $0.99 \mathrm{ft}^{3} / \mathrm{s}\left(0.03 \mathrm{~m}^{3} / \mathrm{s}\right)$ just below Lucky Peak Dam to $1,010 \mathrm{ft}^{3} / \mathrm{s}\left(28 \mathrm{~m}^{3} / \mathrm{s}\right)$ at the mouth of the river, a distance of $64 \mathrm{mi}(103 \mathrm{~km}$ ) (figs. 8 and 21). The measurements indicate that the major inflows to Boise River are from large drainage channels in the downstream half of the reach, below Star Road. Ground-water inflow directly to the Boise River channel or to short surface drains flowing into the Boise River averaged about $3\left(\mathrm{ft}^{3} / \mathrm{s}\right) / \mathrm{mi}$ or $0.055\left(\mathrm{~m}^{3} / \mathrm{s}\right) / \mathrm{km}$ and was relatively uniform in the reach.

Surface drainage channels contributed about 80 percent of the inflow to the river system. The seven largest channels, Fifteenmile Creek, Mill Slough (including its tributary at Middleton), Mason Creek, Hartley Gulch, Indian Creek, Dixie Slough, and Sand Run contributed $690 \mathrm{ft}^{3} / \mathrm{s}\left(20 \mathrm{~m}^{3} / \mathrm{s}\right)$ or 68 percent of the total inflow to the study reach. Nearly 60 percent of the inflow, $601 \mathrm{ft}^{3} / \mathrm{s}\left(17 \mathrm{~m}^{3} / \mathrm{s}\right)$ entered the system in the $20-\mathrm{mi}(32-\mathrm{km})$ distance between Star Road and the gage at Notus. Of this inflow, about 85 percent was contributed by five drains: Fifteenmile Creek, Mason Creek, Hartley Gulch, Mill Slough (including its tributary at Middleton), and Indian Creek. 
Table 2. Summary of surface-water flow (ground-water discharge) in the Boise River valley, November 18-19, 1971.

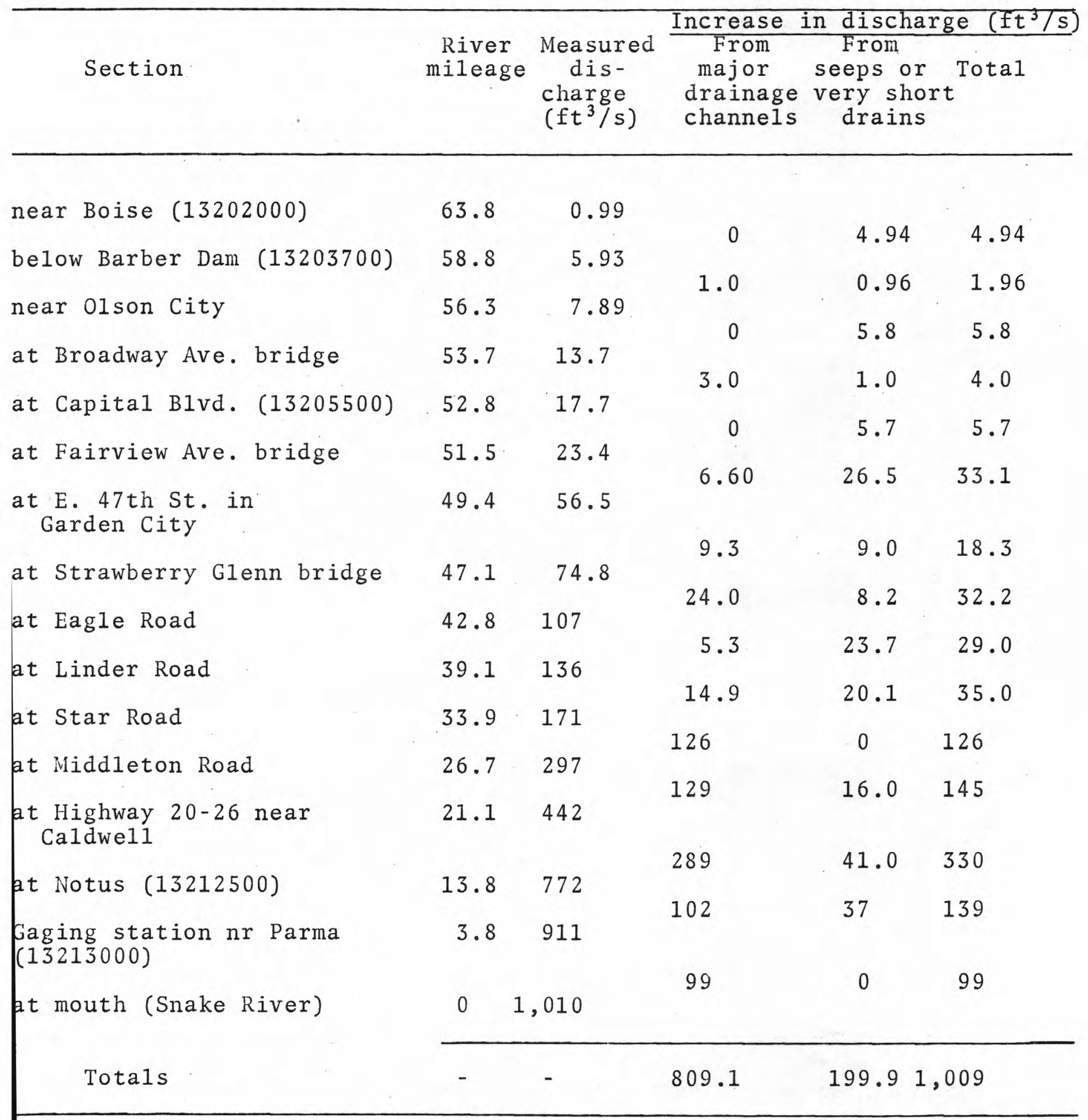


DISTANCE, IN KILOMETERS, DOWNSTREAM FROM GAGING STATION 13202000

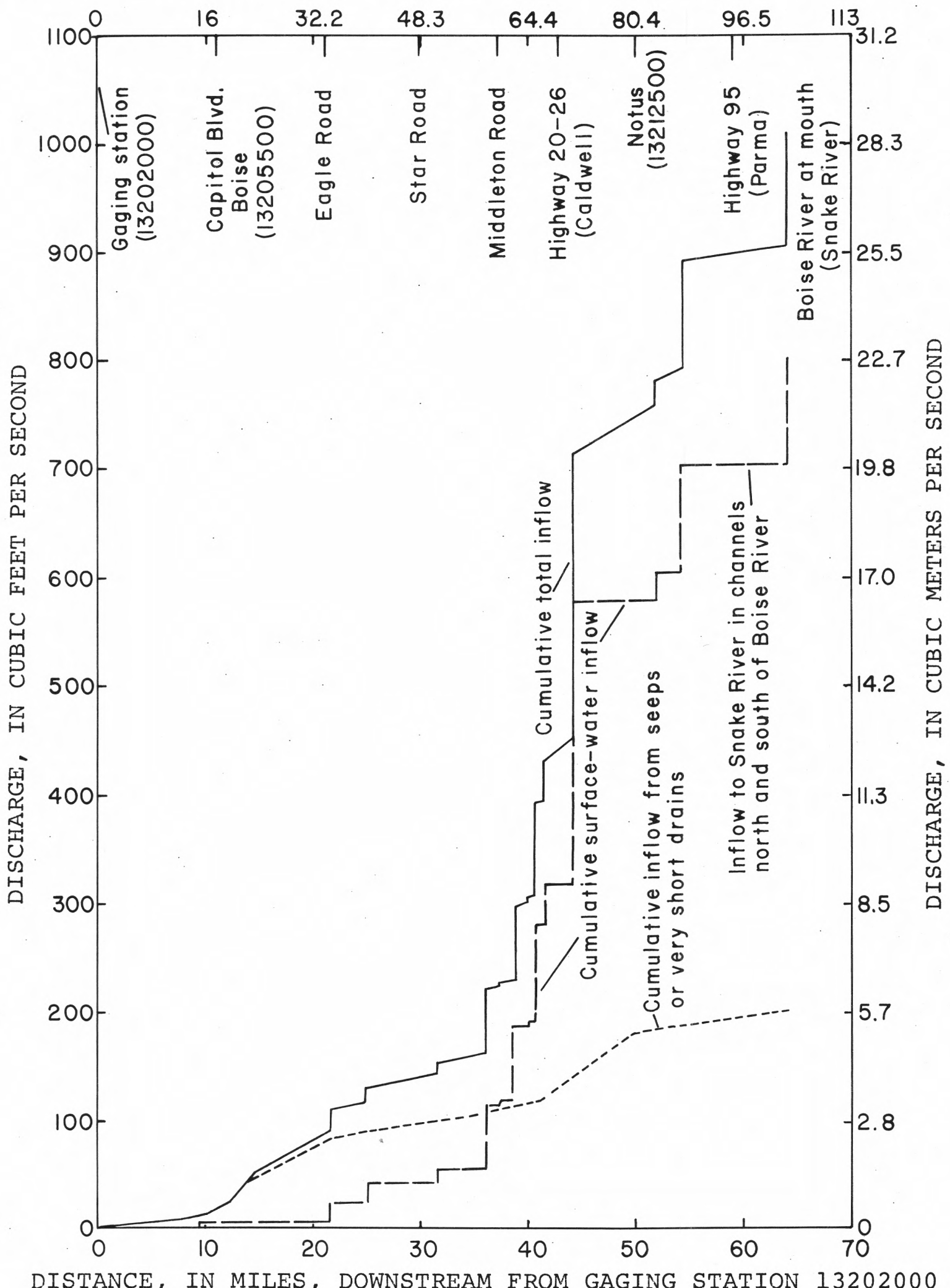

FIGURE 21.--Graph of cumulative inflow to the Boise River between Lucky Peak Dam and mouth November 18-19, 1971. 
Sand Run and South Boise Drain discharge directly into the Snake River, but both carry water most of which was previously diverted from the Boise River for irrigation. For this reason, they are combined with the Boise River system in the pictorial presentation on figure 8 .

The inflow to the Boise River as measured in November 1971 was probably slightly above average. The 1956-70 average inflow between the gages at Boise and at Notus for November is $696 \mathrm{ft}^{3} / \mathrm{s}\left(20 \mathrm{~m}^{3} / \mathrm{s}\right)$, whereas the measured inflow on November 18 is $732 \mathrm{ft}^{3} / \mathrm{s}\left(21 \mathrm{~m}^{3} / \mathrm{s}\right)$. By comparison, the average inflow for November 1961, following a season of relatively low water application for irrigation, was $587 \mathrm{ft}^{3} / \mathrm{s}$ $\left(17 \mathrm{~m}^{3} / \mathrm{s}\right)$. Inflow between the gages usually becomes less through the winter months as the water table in the aquifer declines.

\section{Water Quality}

During 1965-72, 68 samples of water were collected from the Boise River at the gaging station near Boise for discharges ranging from 0.99 to $9,720 \mathrm{ft}^{3} / \mathrm{s}(0.02$ to $275 \mathrm{~m}^{3} / \mathrm{s}$ ). Dissolved-solids concentrations of these samples ranged from 38 to $82 \mathrm{mg} / 1$ and bore little relation to discharge. The water discharged from the reservoir reflects the composite dissolved-solids concentration of water flowing into the reservoirs during the previous runoff season or seasons. Its chemical characteristics are virtually unrelated to the rate at which it is released from the reservoir.

Water quality was analyzed once a month or more frequently downstream at the gaging station Boise River at Notus for the same period, and the analyses showed a much wider range in the dissolved-solids concentration. A few of these samples contained less than $90 \mathrm{mg} / 1$ of dissolved solids when large outflows from Lucky Peak Lake diluted the groundwater inflows upstream from Notus. The historical water-quality record at Notus indicates that at times the concentration of dissolved solids may be much higher than observed during the November 1971 low flow. The maximum dissolved-solids concentration of $914 \mathrm{mg} / 1$ observed there in August 1939 is about twice that observed in 1971 at this location. Other waterquality data in the files of the Geological Survey and other agencies indicate that, in general, the biochemical-oxygen demand and nutrient concentrations increase and dissolvedoxygen concentrations decrease in a downstream direction in the Boise River. 
Concurrent with the discharge measurements made November 18-19, 1971, 38 water samples were collected from the Boise River and its tributaries. Specific conductance and chloride concentrations were measured for all samples collected. Dissolved-solids concentrations were estimated by multiplying specific-conductance values by the factor 0.67 . In addition, 10 selected samples were analyzed for silica, calcium, magnesium, sodium, potassium, bicarbonate, carbonate, sulfate, chloride, fluoride, total nitrogen, total nitrite plus nitrate, total ammonia nitrogen, total organic nitrogen, total phosphorus, total orthophosphorus, dissolved solids, specific conductance, $\mathrm{pH}$, dissolved oxygen (four samples only), biochemical-oxygen demand, total coliform (two samples only) and fecal coliform (four samples only). The specificconductance, dissolved-solids and chloride data are given in appendix $B$; the results of the 10 more complete analyses are given in table 3 .

Surface water in the upper end of the study reach is $10 \mathrm{w}$ in dissolved solids. The lowest calculated value, $60 \mathrm{mg} / 1$, was measured in samples collected at the uppermost station, Boise River near Boise, at a flow of only $0.99 \mathrm{ft}^{3} / \mathrm{s}\left(0.03 \mathrm{~m}^{3} / \mathrm{s}\right)$. All ground-water seepage and tributary flow into the river below this point was considerably higher in dissolved solids. In general, dissolved-solids concentrations in Boise River increased gradually downstream to a maximum of $462 \mathrm{mg} / 1$ at the mouth. One exception to this trend was noted immediately downstream from the outfall of the Boise sewage-treatment plant. As shown in figure 8 , the dissolved-solids concentration exceeded less than $200 \mathrm{mg} / 1$ immediately below the outfall, but it was diluted to less than $200 \mathrm{mg} / 1$ within a short distance downstream. The series of diagrams (Stiff, 1951) presented in figure 8 illustrate the buildup of selected ions as the water flows through the study area. Records for 1971 show that the predominantly calcium bicarbonate type water found at the upstream end of the area changes to a predominantly sodium bicarbonate type water at the downstream end of the area when the return flow is predominantly ground water, as is common during the nonirrigation season.

The increase in concentration of dissolved salts as the water flows downstream leads to a distinct change in the ratio of dissolved sodium to calcium. The concentration of calcium bicarbonates can and does increase to a level where it is in chemical equilibrium with solid calcium carbonate; whereupon no more can dissolve. The sodium concentration continues to increase long after that of calcium has been restricted by the relatively low solubility of calcium carbonate. As a consequence, the ratio of sodium to calcium increases as additional salts are picked up during downstream movement of the water. High sodium ratios in irrigation waters are a serious problem in some regions of the world, though in no case were the ratios observed during this study found to approach a level that would be hazardous to agriculture. 
Table 3. Summary of standard chemical analyses of surface water in Boise River and tributaries, November 18-19, 1971.

\begin{tabular}{|c|c|c|c|c|c|c|c|c|c|c|c|c|}
\hline & 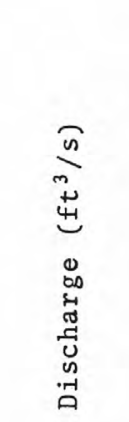 & 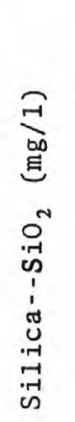 & 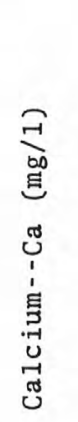 & 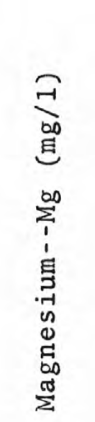 & 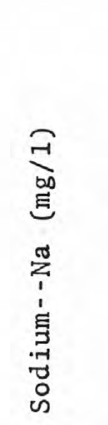 & 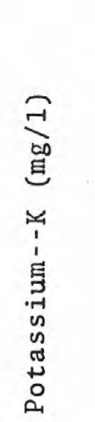 & 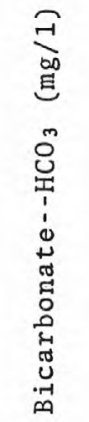 & 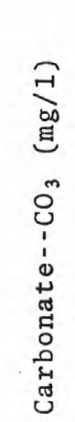 & 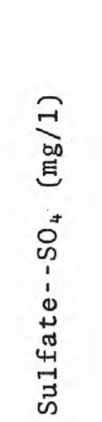 & 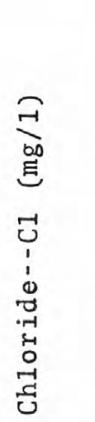 & 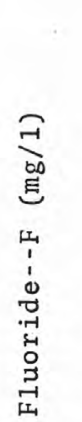 & 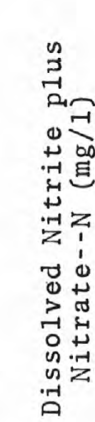 \\
\hline $\begin{array}{l}\text { South Boise Drain } \\
\text { near Parma }\end{array}$ & 20.2 & 55. & 55. & 25. & 130 . & 13. & 430 . & 0 & 120. & 37. & 0.9 & 2.5 \\
\hline $\begin{array}{l}\text { Boise River near } \\
\text { Boise }(13202000)\end{array}$ & 0.99 & 13. & 12. & 1.5 & 4.5 & 0.8 & 52. & 0 & 0 & 1.5 & 0.3 & .13 \\
\hline $\begin{array}{l}\text { Boise River at } \\
\text { Fairview Bridge }\end{array}$ & 23.1 & 16. & 22 . & 3.6 & 13. & 1.6 & 98 . & 0 & 8.3 & 8.1 & 0.5 & .41 \\
\hline $\begin{array}{l}\text { Fivemile Creek } \\
\text { at Star Road }\end{array}$ & 35.8 & 41. & 56. & 18. & 70 . & 3.5 & 322 . & 11. & 62. & 14. & 0.7 & 2.7 \\
\hline $\begin{array}{l}\text { Mason Creek } \\
\text { at mouth }\end{array}$ & 89.0 & 46. & 59. & 19. & 82. & 3.8 & 334 . & 0 & 92 . & 16. & 0.8 & 5.0 \\
\hline $\begin{array}{l}\text { West End Drain } \\
\text { at Hwy } 19\end{array}$ & 37.5 & 50 . & 58. & 17. & 120 . & 5.2 & 386. & 0 & 110 . & 34. & 0.9 & 3.3 \\
\hline $\begin{array}{l}\text { Pipe Gulch } \\
\text { at Hwy } 69\end{array}$ & 23.2 & 54. & 40 . & 21. & 79. & 3.6 & 295 . & 0 & 75. & 23. & 0.8 & 3.6 \\
\hline $\begin{array}{l}\text { Dixie Slough } \\
\text { at mouth }\end{array}$ & 102. & 49 . & 53. & 19. & 110 . & 5.2 & 371. & 0 & 93. & 31. & 0.9 & 1.9 \\
\hline $\begin{array}{l}\text { Boise River } \\
\text { at mouth }\end{array}$ & 896 . & 38. & 51. & 16. & 82. & 6.6 & 293. & 0 & 79. & 32. & 0.7 & 2.5 \\
\hline $\begin{array}{l}\text { Sand Run Gulch } \\
\text { at mouth }\end{array}$ & 76.5 & 45. & 62. & 19. & 99 . & 5.9 & 336. & 0 & 110 . & 42. & 0.6 & 2.8 \\
\hline
\end{tabular}


Table 3--Continued

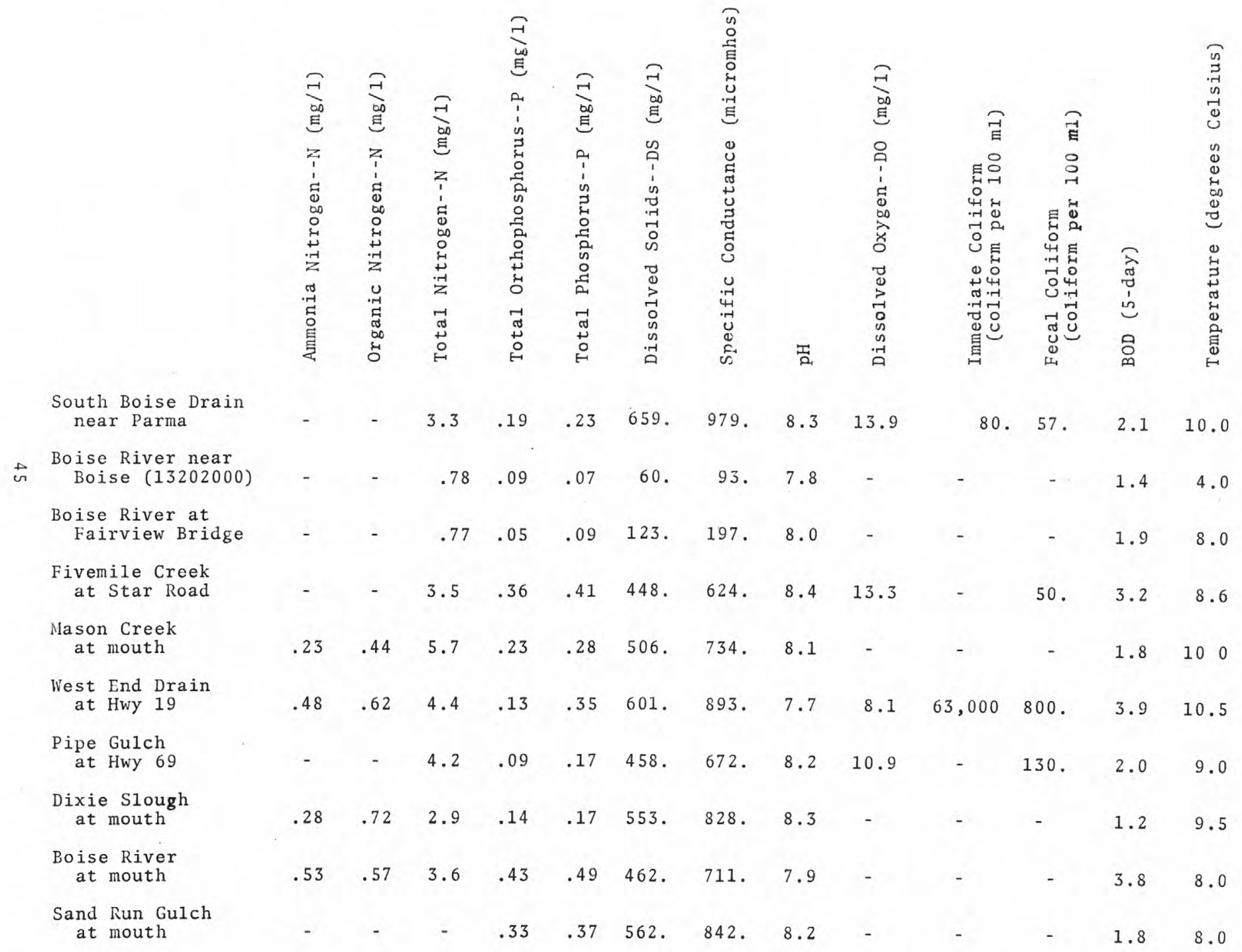


Concentrations of individual constituents also increased downstream. Chloride concentrations increased from $1.5 \mathrm{mg} / 1$ at the uppermost station to $32 \mathrm{mg} / 1$ at the mouth of the river. A downstream increase in sulfate concentration was even more pronounced, from 0 to $79 \mathrm{mg} / 1$, and sodium concentrations increased from 4.5 to $82 \mathrm{mg} / 1$. An increase in dissolved constituents with flow downstream is characteristic of almost all streams in arid and semiarid regions. While notable increases were observed along the Boise River from Lucky Peak Dam to the mouth of the river, the practical consequences are minimal. The concentration of no single ion increases to a hazardous level, although the total dissolved-solids concentration does increase in the lower reach of the river. Some adverse reaction might be expected if the water were applied for irrigation of some saltsensitive crops.

Data on nutrient concentrations were collected at 10 stations (table 3 ). Total nitrogen concentrations increased from about $0.8 \mathrm{mg} / 1$ at the upstream end to $3.6 \mathrm{mg} / 1$ at the mouth, and phosphorus increased from about 0.1 to $0.5 \mathrm{mg} / 1$. These concentrations are not objectionable for most uses of water, but under the right conditions, are high enough to support algal blooms.

The BOD or 5-day biochemical-oxygen demand (10 samples) and the DO or dissolved-oxygen concentrations (4 samples) for November 18-19, 1971, were within the tolerance levels of fish life presented by McKee and Wolf (1963, p. 147, 179181). However, the dissolved-oxygen samples were collected in the afternoon, when concentrations usually are relatively high. Dissolved-oxygen concentrations usually decrease at night, owing to a diurnal change in metabolic processes of aquatic plants. The limited number of samples analyzed for BOD and DO were not sufficient to indicate extremes.

Likewise, the limited analyses of coliform bacteria are not sufficient to indicate their concentration or distribution in the system. Coliform bacteria are normally present in most surface streams as substantiated by data in the files of the Geological Survey and other agencies.

Those waters in the western part of the study area having dissolved-solids concentrations greater than $480 \mathrm{mg} / 1$ would be classed as having a high salinity hazard with respect to use for irrigation (U.S. Salinity Laboratory Staff, 1954 , p. 80,157$)$. The reach of the Boise River between the Fairview Street bridge and its confluence with the Snake River is rated as having a medium salinity hazard ( 160 to $480 \mathrm{mg} / 1$ dissolved-solids concentrations). The Boise River is rated as having a low salinity hazard (dissolved solids less than $160 \mathrm{mg} / 1$ ) between the Fairview Street bridge and 
Lucky Peak Dam. Nowhere in the study area were the sodium concentrations measured high enough to produce a sodium hazard with respect to irrigation use.

Water temperatures seldom exceed $18^{\circ} \mathrm{C}\left(65^{\circ} \mathrm{F}\right)$ at the outlet of Lucky Peak Dam. Water temperatures as high as $29^{\circ} \mathrm{C}\left(84^{\circ} \mathrm{F}\right)$ have been recorded at Notus.

\section{CONCLUSIONS}

Streamflow characteristics for the Boise River, including water quality, are drastically affected by regulation, large diversions, and the heavy consumptive use of the water on irrigated lands.

The redistribution with time of flow in the river results in (1) a reduction of natural flood flows by more than 50 percent in the study reach; (2) a reduction of low flows to critical levels for some purposes for relatively long periods; and (3) extended periods of medium-high flows that cause seepage problems and other high-water problems on low-lying areas on the flood plain.

During the irrigation season, demands to fill irrigation needs result in relatively high, well-sustained flows in the upper end of the study reach. During this season, flows sometimes become critically low for some purposes at some points, especially near Star and Notus.

During the nonirrigation season, the pattern is somewhat reversed. Flows are critically low for some purposes in the upper sections of the study reach when gates are lowered at Lucky Peak Dam. Inflow to the river, practically all of which is from ground-water discharge, provides sizable, well-sustained flows in the lower end of the study reach, especially below Star. Based on the measurements of November 17-18, 1971, about 80 percent of the discharge from ground water enters the river via surface streams. Nearly 70 percent enters Boise River below Star in seven major drainage channels. In general, the ground-water discharge decreases from the end of the irrigation season to the beginning of the next irrigation season.

The reduction of peak flows downstream from Lucky Peak Dam has lessened the ability of the river to transport sediment and has caused aggradation of its channel. Willow and other growth in and near the channel has increased, thus decreasing the capacity of the channel to carry flow without overbank flooding. 
In general, the quality of water deteriorates in a downstream direction and water temperatures increase. Quality at the lower end of the reach improves when the dilution by fresher water released from Lucky Peak Lake increases.

\section{SELECTED REFERENCES}

Dion, N. P., 1972, Some effects of land-use changes on the shallow ground-water system in the Boise-Nampa area, Idaho: Idaho Dept. Water Adm. Water Inf. Bull. 26, $47 \mathrm{p}$.

Fenneman, N. M., 1931, Physiography of Western United States: New York, McGraw-Hill Book Co., 534 p.

McKee, J. E, , and Wolf, H. W., 1963, Water quality criteria: The Resources Agency of California State Water Quality Control Board Pub. No. 3-A, $551 \mathrm{p}$.

Nace, R. L., West, S. W., and Mower, R. W., 1957, Feasibility of ground-water features of the alternate plan for the Mountain Home Project, Idaho: U.S. Geol. Survey WaterSupply Paper $1376,121 \mathrm{p}$.

Savage, C. N., 1958, Geology and mineral resources of Ada and Canyon Counties: Idaho Bur. Mines and Geology County Rept. no. 3, 94 p.

Searcy, J. K., 1959, Flow-duration curves: U.S. Geol. Survey Water-Supp1y Paper 1542-A, $33 \mathrm{p}$.

Stevlingson, D. J., and Everson, D. O., 1968, Spring and fall freezing temperatures in Idaho: Idaho Agr. Expt. Sta. Bull. $494,19 \mathrm{p}$.

Stiff, H. A., Jr., 1951, The interpretation of chemical water analyses by means of patterns: Jour. of Petroleum Technology, v. 3, no. 10, p. 15-17.

Thomas, C. A., 1963, Cloudburst floods at Boise, Idaho, August 20, September 22, 26, 1959: U.S. Geol. Survey open-file rept., $12 \mathrm{p}$.

U.S. Geological Survey, 1973, Water resources data for Idaho, 1972 annual report: U.S. Geol. Survey, $289 \mathrm{p}$.

U.S. Salinity Laboratory Staff, 1954, Diagnosis and improvement of saline and alkali soils: U.S. Dept. Agr. Handb. $60,160 \mathrm{p}$.

U.S. Public Health Service, 1962, Drinking-water standards, 1962: U.S. Public Health Service Pub. 956, $61 \mathrm{p}$. 
APPENDIX A 


\section{APPENDIX A}

Ground-water levels measured in the vicinity of the Boise River, November 18-19, 1971.

WELL NUMBER

$\begin{array}{rr}5 N-5 W-17 c c & 1 \\ 18 c c & 1 \\ 28 c b & 1 \\ 29 b d & 1 \\ 34 d c & 1\end{array}$

$5 \mathrm{~N}-4 \mathrm{~W}-33 \mathrm{bb} 1$

$4 \mathrm{~N}-5 \mathrm{~W}-12 \mathrm{cb} 1$

$4 \mathrm{~N}-4 \mathrm{~W}-11$ daal

24 bd 1

$25 \mathrm{dc} 2$

$26 \mathrm{bd} 1$

$4 \mathrm{~N}-3 \mathrm{~W}-24$ ac 1

24 dd 2

$25 \mathrm{ca} 1$

$31 \mathrm{db} 1$

$4 \mathrm{~N}-3 \mathrm{~W}-34 \mathrm{cb} \quad 1$

$35 \mathrm{cc} 1$

$4 \mathrm{~N}-2 \mathrm{~W}-3 \mathrm{abcl}$

5 bad1

$11 \mathrm{dbb} 1$

19 ada 1

2 2dcd 1

24 ccc 1

$26 \mathrm{cad} 1$

27 bbal

$29 \mathrm{ccb} 1$

31dda1

$35 \mathrm{cdd} 1$

$4 N-1 W-2 a a b 1$

4ddal
ALTITUDE OF

LAND SURFACE

(FT)
DEPTH TO

WATER (FT)

BELOW LAND

SURFACE
ALTITUDE OF

WATER SURFACE

(FT)
12.44 a/

$13.92 \mathrm{a} /$
26.90 /

27.90

72.77

2,292

2,290

2,415

2,310

2,328

2,420

2,413

2,412

2,416

2,415

2,454

2,428

2,422

2,440

2,420

2,442

2,421

2,458

2,479

2,472

2,441

2,432

2,438

2,479

2,552

2,523
6.91 a/

14.74

7.73

8.91

40.21

50.47

20.07

7.50

11.68

44.10 a /

20.80

17.32

14.42

9.57

13.58

4.27

22.98

11.07

1.82

10.79

8.65

11.61

7.89

23.02
9.75 a
2,229 a.

2,215

2,258 a

2,264

2,342

$2,283^{\text {a/ }}$

2,400

2,302

2,319

2,380

2,363

2,392

2,408

2,403

2,410 a/

2,407

2,405

2,426

2,410

2,432 a

2,407

2,454

2,456

2,461

2,439

2,421

2,429

2,467

2,544

2,500 
WELL NUMBER

\begin{tabular}{|c|c|c|c|}
\hline $\begin{array}{r}8 \mathrm{dcd} 1 \\
12 \mathrm{ddb} 1 \\
13 \mathrm{ccdl} 1 \\
15 \mathrm{bbb1} \\
22 \mathrm{dbb1}\end{array}$ & $\begin{array}{l}2,475 \\
2,531 \\
2,515 \\
2,493 \\
2,545\end{array}$ & $\begin{array}{l}4.55 \text { a } \\
4.17 \\
2.87 \text { a/ } \\
5.60 \text { - } \\
42.19\end{array}$ & $\begin{array}{l}2,470 \text { al } \\
2,527 \\
2,512 \mathrm{a} / \\
2,487- \\
2,503\end{array}$ \\
\hline $\begin{array}{r}4 \mathrm{~N}-1 \mathrm{~W}-31 \text { bdd } 1 \\
32 \mathrm{aaa} 2 \\
34 \text { dad1 } \\
35 \text { aaal } \\
4 \mathrm{~N}-1 \mathrm{E}-\quad 4 \text { bbc1 }\end{array}$ & $\begin{array}{l}2,499 \\
2,519 \\
2,548 \\
2,573 \\
2,625\end{array}$ & $\begin{array}{l}2.17 \\
4.47 \\
6.14 \text { a / } \\
7.40 \\
44.80\end{array}$ & $\begin{array}{l}2,497 \\
2,515 \text { al } \\
2,542 \text { - } \\
2,566 \\
2,580\end{array}$ \\
\hline $\begin{array}{r}8 \mathrm{dcb} 1 \\
10 \mathrm{bbc1} \\
13 \mathrm{bdb} 1 \\
21 \mathrm{ccc} 1 \\
23 \mathrm{adc1}\end{array}$ & $\begin{array}{l}2,563 \\
2,625 \\
2,630 \\
2,616 \\
2,594\end{array}$ & $\begin{array}{r}8.00 \\
47.33 \\
31.08 \\
41.21 \\
4.47\end{array}$ & $\begin{array}{l}2,555 \\
2,578 \\
2,599 \\
2,575 \\
2,590\end{array}$ \\
\hline $\begin{array}{l}27 \text { addl } \\
28 \text { aab2 } \\
29 \text { bbb1 } \\
31 \text { acdl } \\
34 \text { aad1 }\end{array}$ & $\begin{array}{l}2,652 \\
2,632 \\
2,600 \\
2,600 \\
2,657\end{array}$ & $\begin{array}{r}25.10 \\
35.33 \\
23.42 \\
7.87 \\
12.88\end{array}$ & $\begin{array}{l}2,627 \\
2,597 \\
2,577 \\
2,592 \\
2,644\end{array}$ \\
\hline $\begin{array}{r}36 \mathrm{bbb1} 1 \\
4 \mathrm{~N}-2 \mathrm{E}-19 \mathrm{abd} 1 \\
19 \mathrm{ccc} 1 \\
28 \mathrm{ccb} 1 \\
33 \mathrm{cad1}\end{array}$ & $\begin{array}{l}2,669 \\
2,695 \\
2,621 \\
2,674 \\
2,675\end{array}$ & $\begin{array}{c}18.67 \mathrm{a} / \\
71.37 \\
7.25 \\
16.47 \\
9.54\end{array}$ & $\begin{array}{l}2,650 \text { a/ } \\
2,624 \\
2,614 \\
2,658 \\
2,665\end{array}$ \\
\hline $\begin{array}{r}4 \mathrm{~N}-2 \mathrm{E}-34 \mathrm{bcc} 1 \\
3 \mathrm{~N}-1 \mathrm{E}-1 \text { daa1 } \\
2 \mathrm{aba1} \\
3 \mathrm{bba1} \\
5 \mathrm{aab} 2\end{array}$ & $\begin{array}{l}2,705 \\
2,690 \\
2,671 \\
2,644 \\
2,616\end{array}$ & $\begin{array}{r}29.86 \\
7.80 \\
8.12 \\
13.95 \\
7.78\end{array}$ & $\begin{array}{l}2,675 \\
2,682 \\
2,663 \\
2,630 \\
2,608\end{array}$ \\
\hline
\end{tabular}

DEPTH TO

ALTITUDE OF LAND SURFACE

(FT)
WATER (FT)

BELOW LAND

SURFACE
ALTITUDE OF WATER SURFACE

(FT) 
WELL NUMBER

$\begin{array}{cl}\text { ALTITUDE OF } & \text { WATER (FT) } \\ \text { LAND SURFACE } & \text { BELOW LAND } \\ \text { (FT) } & \text { SURFACE }\end{array}$

ALTITUDE OF WATER SURFACE (FT)

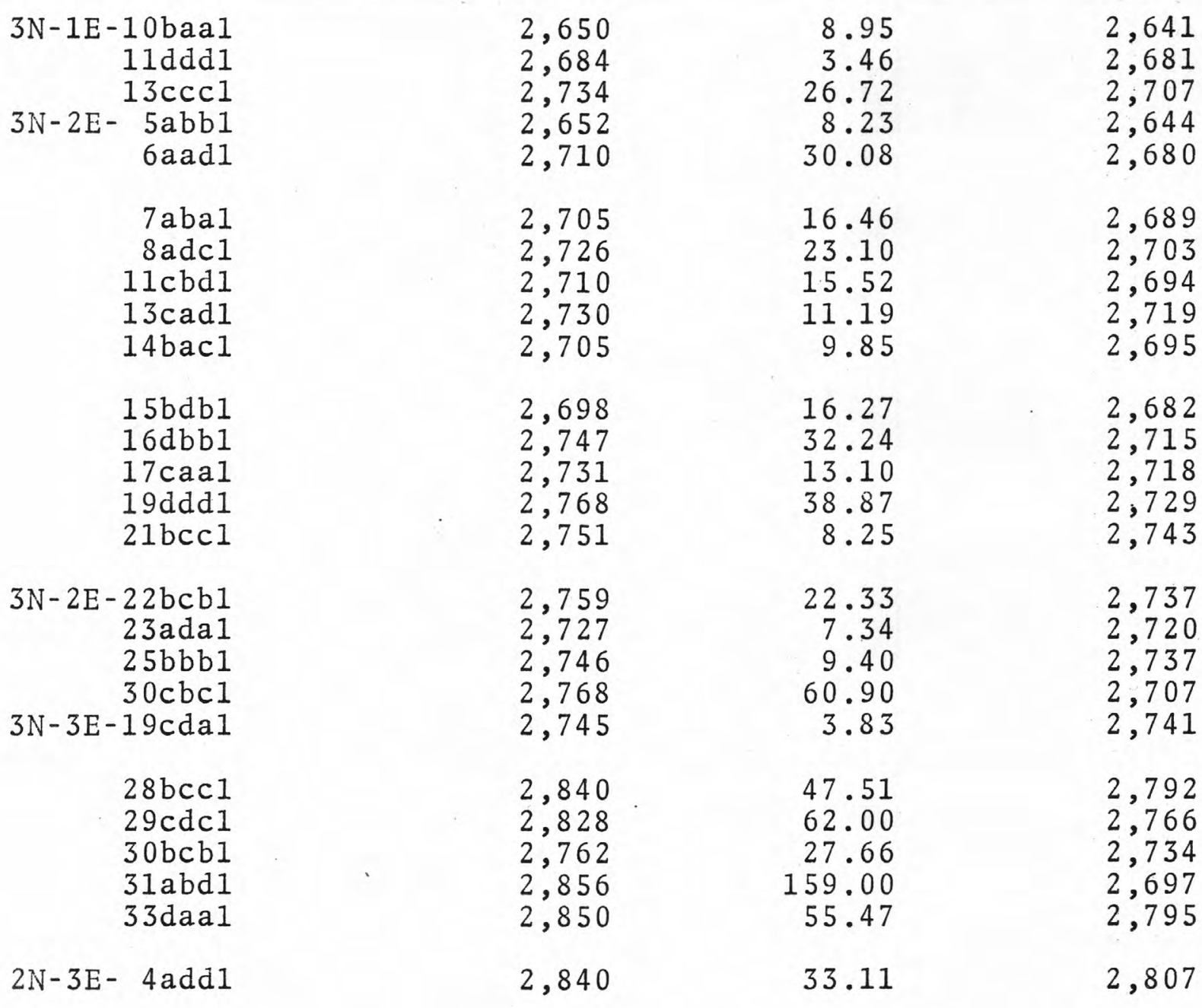

a/ Well recently pumped prior to measurement. 
APPENDIX B

53 
Summary of partial chemical analyses of water samples from the Boise River and from tributary watercourses with discharges greater than 10 cubic feet per second, November 18-19, 1971 .

\begin{tabular}{|c|c|c|c|c|c|c|}
\hline Station & Location & $\begin{array}{c}\text { Discharge } \\
11-18-71 \\
\left(\mathrm{ft}^{3} / \mathrm{s}\right)\end{array}$ & $\begin{array}{l}\text { Chloride } \\
(\mathrm{mg} / 1)\end{array}$ & $\begin{array}{l}\text { Dis- } \\
\text { solved } \\
\text { solids } \\
(\mathrm{mg} / 1)\end{array}$ & $\begin{array}{l}\text { Specific } \\
\text { conduct- } \\
\text { ance } \\
\text { (micro- } \\
\text { mhos) }\end{array}$ & $\begin{array}{l}\text { Temper } \\
\text { ature } \\
\left({ }^{\circ} \mathrm{C}\right)\end{array}$ \\
\hline \multicolumn{7}{|c|}{ Main stem of Boise River ${ }^{2}$} \\
\hline near Boise $(13202000)^{3}$ & $\mathrm{SEE}_{\frac{1}{4}} \mathrm{NE}_{\frac{1}{4}} \mathrm{NE} \mathrm{I}_{4}^{\frac{1}{4}} \mathrm{sec} .10, \mathrm{~T}, 2 \mathrm{~N}, \mathrm{R}, 3 \mathrm{E}$. & 0.99 & 1.5 & 60 & 93 & 4.0 \\
\hline $400 \mathrm{ft}$ below Barber Dam & $\mathrm{SW}_{\frac{1}{4}} \mathrm{SW}_{\frac{1}{4}} \mathrm{SE}_{\frac{1}{4}} \mathrm{sec} .29$, T. $3 \mathrm{~N}$, , R. $3 \mathrm{E}$. & 5.93 & 2.0 & $(107)$ & 159 & 4.0 \\
\hline $\begin{array}{l}\text { at power line crossing, } \\
\text { above Olson City }\end{array}$ & $N_{W} \frac{1}{4} N W_{\frac{1}{4}} S E \frac{1}{4} \sec .24$, T. 3 N., R. 2 E. & 6.89 & 2.0 & (111) & 165 & 5.0 \\
\hline at Broadway Avenue bridge & $\mathrm{NE}_{\frac{1}{4}} \mathrm{NE}_{\frac{1}{4}} \mathrm{NE}_{\frac{1}{4}} \mathrm{sec}, 15, \mathrm{~T}, 3$ N., R. 2 E. & 13.7 & 2.1 & $(107)$ & 160 & 6.5 \\
\hline at Boise $(13205500)$ & $\operatorname{SE}_{\frac{1}{4}} N W_{\frac{1}{4}} S W_{\frac{1}{4}} \sec .10$, T. 3 N., R. 2 E. & 13.9 & 2.1 & $(101)$ & 151 & 6.0 \\
\hline at Fairview Avenue bridge ${ }^{3}$ & $\mathrm{SE}_{\frac{1}{4}} \mathrm{SW}_{\frac{1}{4}} \mathrm{SW}_{\frac{1}{4}} \sec .4, \mathrm{~T}, 3 \mathrm{~N}, \mathrm{R}, 2 \mathrm{E}$. & 23.1 & 8.1 & 123 & 197 & 8.0 \\
\hline at E. 47 th St. in Garden & SW $\frac{1}{4} S W_{\frac{1}{4}} N W_{\frac{1}{4}} \sec .32$, T. 4 N., R. 2 E. & 56.5 & 16 & $(225)$ & 335 & 9.5 \\
\hline $\begin{array}{l}\text { at Strawberry Glenn Road } \\
\text { bridge }\end{array}$ & $\mathrm{NW}_{\frac{1}{4}} \mathrm{NW}_{\frac{1}{4}} \mathrm{NE}_{\frac{1}{4}} \mathrm{sec} .25, \mathrm{~T} .4 \mathrm{~N} ., \mathrm{R} .1 \mathrm{E}$. & 65.4 & 11 & $(183)$ & 273 & - \\
\hline $\begin{array}{l}\text { at Eagle Road (north } \\
\text { channel) }\end{array}$ & SW $\frac{1}{4} S W_{\frac{1}{4}} N W_{\frac{1}{4}} \sec .16$, T. 4 N., R. 1 E. & 35.8 & 12 & $(180)$ & 269 & 5.5 \\
\hline $\begin{array}{l}\text { at Eagle Road (south } \\
\text { channel) }\end{array}$ & SW $\frac{1}{4} N W_{\frac{1}{4}} N W^{\frac{1}{4}} \sec .21, T \cdot 4 \mathrm{~N},, \mathrm{R}, 1 \mathrm{E}$. & 32.7 & 13 & $(199)$ & 297 & 5.5 \\
\hline $\begin{array}{l}\text { at Linder Road (north } \\
\text { channe1) }\end{array}$ & $\mathrm{NE}_{\frac{1}{4}} \mathrm{SE}_{\frac{1}{4}} \mathrm{NEE}_{\frac{1}{4}} \mathrm{sec} .14, \mathrm{~T}, 4 \mathrm{~N},, \mathrm{R}, 1 \mathrm{~W}$. & $60.9^{\circ}$ & 9.1 & $(180)$ & 268 & 8.0 \\
\hline $\begin{array}{l}\text { at Linder Road (south } \\
\text { channe1) }\end{array}$ & $\mathrm{SE}_{\frac{1}{4}} \mathrm{NE}_{\frac{1}{4}} \mathrm{NE}_{\frac{1}{4}} \mathrm{sec} .25, \mathrm{~T} .4 \mathrm{~N} ., \mathrm{R} .1 \mathrm{~W}$. & 69.7 & 4.4 & $(278)$ & 414 & 8.0 \\
\hline at Star Road & $\mathrm{NW}_{\frac{1}{4}} \mathrm{SW}_{\frac{1}{4}} \mathrm{SW} \frac{1}{4} \sec .17, \mathrm{~T}, 4 \mathrm{~N},, \mathrm{R}, 1 \mathrm{~W}$. & 154 & 3.6 & (219) & 326 & 6.0 \\
\hline at Middleton Road & SW $\frac{1}{4} N W_{\frac{1}{4}} S W_{\frac{1}{4}} \sec .8$, T. 4 N., R. 2 W. & 214 & 9.7 & $(282)$ & 420 & 7.5 \\
\hline
\end{tabular}




\begin{tabular}{|c|c|c|c|c|c|c|}
\hline Station & Location & $\begin{array}{c}\text { Discharge } \\
11-18-71 \\
\left(\mathrm{ft}^{3} / \mathrm{s}\right)\end{array}$ & $\begin{array}{c}\text { Chloride } \\
\text { (mg/1) }\end{array}$ & $\begin{array}{l}\text { Dis- } \\
\text { solved } \\
\text { solids } \\
(\mathrm{mg} / 1)\end{array}$ & $\begin{array}{l}\text { Specific } \\
\text { conduct- } \\
\text { ance } \\
\text { (micro- } \\
\text { mhos) }\end{array}$ & $\begin{array}{c}\text { Temper- } \\
\text { ature } \\
\left({ }^{\circ} \mathrm{C}\right)\end{array}$ \\
\hline $\begin{array}{l}\text { at Highway } 20-26 \text { crossing, } \\
\text { near Caldwell }\end{array}$ & $\mathrm{SEE}_{\frac{1}{4}} \mathrm{NW}^{\frac{1}{4}} \mathrm{SW} \mathrm{W}^{\frac{1}{4}} \mathrm{sec} .15, \mathrm{~T} .4 \mathrm{~N} ., \mathrm{R} .3 \mathrm{~W}$. & 441 & 13 & $(352)$ & 525 & 6.5 \\
\hline at Notus $(13212500)$ & $\mathrm{NE}^{\frac{1}{4}} \mathrm{SE}_{\frac{1}{4}} \mathrm{SE}^{\frac{1}{4}} \mathrm{sec} .34, \mathrm{~T} .5 \mathrm{~N} ., \mathrm{R}, 4 \mathrm{~W}$. & 746 & 26 & $(450)$ & 671 & 11.5 \\
\hline $\begin{array}{l}\text { at Highway } 95 \text { crossing, } \\
\text { near Parma }\end{array}$ & $N E^{\frac{1}{4}} N E^{\frac{1}{4}} N E^{\frac{1}{4}} \mathrm{sec} .27$, T. 5 N., R. $5 \mathrm{~W}$. & 867 & 27 & $(470)$ & 700 & 8.0 \\
\hline at mouth (Snake River) ${ }^{3}$ & $\begin{array}{l}\mathrm{SE}^{\frac{1}{4}} \mathrm{SW}_{\frac{1}{4}} N E^{\frac{1}{4}} \text { sec. } 35, \mathrm{~T}, 6 \mathrm{~N}, \text {, R. } 6 \mathrm{~W} . \\
\text { Tributaries, drains, canals, slo }\end{array}$ & 896 & $\begin{array}{c}32 \\
\text { passes }\end{array}$ & 462 & 711 & 8.0 \\
\hline $\begin{array}{l}\text { South Boise drain } \\
\text { near Parma }\end{array}$ & $\mathrm{SW}_{\frac{1}{4}} \mathrm{SW}_{\frac{1}{4}} \mathrm{SW}_{\frac{1}{4}} \mathrm{sec} .12, \mathrm{~T} .5 \mathrm{~N} ., \mathrm{R} .6 \mathrm{~W}$. & 20.2 & 37 & 659 & 979 & - \\
\hline $\begin{array}{l}\text { Eagle drain } \\
\text { near Eagle }\end{array}$ & $\mathrm{NE}_{\frac{1}{4}} \mathrm{SE}_{\frac{1}{4}} \mathrm{SE}_{\frac{1}{4}} \mathrm{sec} .8, \mathrm{~T}, 4 \mathrm{~N}, \mathrm{R}, 1 \mathrm{E}$ & 14.5 & 5.2 & $(222)$ & 330 & 8.5 \\
\hline $\begin{array}{l}\text { Thurman drain } \\
\text { south of Eagle }\end{array}$ & $\mathrm{SE}_{\frac{1}{4}} \mathrm{NE}_{\frac{1}{4}} \mathrm{SE}_{\frac{1}{4}} \mathrm{sec} .20, \mathrm{~T} .4 \mathrm{~N} ., \mathrm{R} .1 \mathrm{E}$. & 20.2 & - & $(370)$ & 566 & 10.5 \\
\hline $\begin{array}{l}\text { Phyllis slough at Highway } \\
\text { crossing south of Star }\end{array}$ & $\mathrm{SE}_{\frac{1}{4}} \mathrm{SE}_{\frac{1}{4}} \mathrm{NE}_{\frac{1}{4}} \mathrm{sec} .19, \mathrm{~T} .4 \mathrm{~N} ., \mathrm{R}, 1 \mathrm{~W}$. & 13.9 & 14 & $(460)$ & 686 & 6.5 \\
\hline$\underset{\text { Road }^{3}}{\text { Fivemile Creek at Star }}$ & $\mathrm{NE}_{\frac{1}{4}} \mathrm{SE}_{\frac{1}{4}} \mathrm{NE}_{\frac{1}{4}} \mathrm{sec} .31, \mathrm{~T} .4 \mathrm{~N} ., \mathrm{R}, 1 \mathrm{~W}$. & 35.8 & 14 & 448 & 624 & - \\
\hline $\begin{array}{l}\text { Fifteenmile Creek near } \\
\text { Middleton }\end{array}$ & $\mathrm{SEE}_{\frac{1}{4}} \mathrm{NE}_{\frac{1}{4}} \mathrm{NW}_{\frac{1}{4}} \mathrm{sec} .21, \mathrm{~T} .4 \mathrm{~N} ., \mathrm{R}, 2 \mathrm{~W}$. & 55.9 & 13 & $(438)$ & 653 & 7.5 \\
\hline Mill slough at Highway 44 & $\mathrm{NE}_{\frac{1}{4}} N W_{\frac{1}{4}} N E_{\frac{1}{4}}$ sec. 7, T. 4 N., R. 2 W. & 15.1 & 22 & $(398)$ & 593 & 11.5 \\
\hline $\begin{array}{l}\text { Unnamed drain between Mill } \\
\text { slough and Boise River }\end{array}$ & $\mathrm{NE}_{\frac{1}{4}} \mathrm{SE}_{\frac{1}{4}} \mathrm{NE}_{\frac{1}{4}} \mathrm{sec}, 7, \mathrm{~T}, 4 \mathrm{~N}, \mathrm{R}, 2 \mathrm{~W}$. & 53.2 & 5.1 & $(259)$ & 386 & 8.5 \\
\hline $\begin{array}{l}\text { Mason Creek at Middleton } \\
\text { Road }\end{array}$ & $\mathrm{SE}_{\frac{1}{4}} \mathrm{SE}_{\frac{1}{4}} \mathrm{SE}_{\frac{1}{4}} \mathrm{sec} .19, \mathrm{~T} .4 \mathrm{~N}, \mathrm{R}, 2 \mathrm{~W}$. & 79.6 & 15 & $(478)$ & 713 & 13.5 \\
\hline
\end{tabular}




\begin{tabular}{|c|c|c|c|c|c|c|}
\hline Station & Location & $\begin{array}{l}\text { Discharge } \\
11-18-71 \\
\left(\mathrm{ft}^{3} / \mathrm{s}\right)\end{array}$ & $\begin{array}{l}\text { Chloride } \\
(\mathrm{mg} / 1)\end{array}$ & $\begin{array}{l}\text { Dis- } \\
\text { solved } \\
\text { solids } \\
(\mathrm{mg} / \mathrm{l})\end{array}$ & $\begin{array}{l}\text { Specific } \\
\text { conduct- } \\
\text { ance } \\
\text { (micro- } \\
\text { mhos) }\end{array}$ & $\begin{array}{l}\text { Temper- } \\
\text { ature } \\
\left({ }^{\circ} \mathrm{C}\right)\end{array}$ \\
\hline ilason Creek at mouth ${ }^{3}$ & $\mathrm{SW}_{\frac{1}{4}} \mathrm{SE}_{\frac{1}{4}} \mathrm{SE}_{\frac{1}{4}} \mathrm{sec} .10, \mathrm{~T} .4 \mathrm{~N} ., \mathrm{R} .3 \mathrm{~W}$. & 89.0 & 16 & 506 & 734 & - \\
\hline fiartley drain near Caldwell & $\mathrm{SW}^{\frac{1}{4}} \mathrm{NE}_{\frac{1}{4}} \mathrm{SW}^{\frac{1}{4}} \mathrm{sec} .10, \mathrm{~T} \cdot 4 \mathrm{~N}, \mathrm{R}, 3 \mathrm{~W}$. & 35.5 & 46 & $(589)$ & 878 & 10.5 \\
\hline Indian Creek at Caldwell & $N E_{\frac{1}{4}} N E^{\frac{1}{4}} S E^{\frac{1}{4}}$ sec. 21, T. 4 N., R. $3 \mathrm{~W}$. & 263 & 35 & $(558)$ & 832 & 13.0 \\
\hline Conway gulch west of Notus & $N E^{\frac{1}{4}} N E_{\frac{1}{4}} \mathrm{SW}^{\frac{1}{4}} \mathrm{sec} .34, \mathrm{~T} .5 \mathrm{~N} ., \mathrm{R} \cdot 4 \mathrm{~W}$. & 25.9 & 60 & $(757)$ & 1,084 & - \\
\hline $\begin{array}{l}\text { West end drain at } \\
\text { Highway } 19^{3}\end{array}$ & $\mathrm{SW}_{\frac{1}{4}} \mathrm{SW}_{\frac{1}{4}} \mathrm{NW}^{\frac{1}{4}} \mathrm{sec} \cdot 23$, T. 4 N., R. $4 \mathrm{~W}$. & 37.5 & 34 & 601 & 893 & - \\
\hline $\begin{array}{l}\text { West end drain south } \\
\text { of Notus }\end{array}$ & $\mathrm{NW}^{\frac{1}{4}} \mathrm{NW}_{\frac{1}{4}} \mathrm{NE}_{\frac{1}{4}}^{\frac{1}{4}}$ sec. 22, T. $4 \mathrm{~N},, \mathrm{R} .4 \mathrm{~W}$. & 39.6 & 32 & $(598)$ & 892 & 11.5 \\
\hline Pipe gulch at Highway $19^{3}$ & 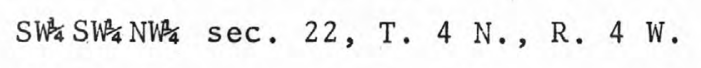 & 23.2 & 23 & 458 & 672 & - \\
\hline Dixie slough at mouth ${ }^{3}$ & $\mathrm{SEF}_{4}^{\frac{1}{4}} \mathrm{NW}_{4} \mathrm{NW}_{4}^{2} \mathrm{sec} .36$, T. $5 \mathrm{~N} ., \mathrm{R}, 5 \mathrm{~W}$. & 102 & 31 & 553 & 828 & 9.5 \\
\hline $\begin{array}{l}\text { Ross east end drain } \\
\text { at Highway } 95\end{array}$ & $\mathrm{SW}^{\frac{1}{4}} \mathrm{NE}^{\frac{1}{4}} \mathrm{SE} \frac{1}{4} \mathrm{sec} .27, \mathrm{~T}, 5 \mathrm{~N},, \mathrm{R}, 5 \mathrm{~W}$. & 11.6 & 47 & $(745)$ & 1,111 & 10.0 \\
\hline $\begin{array}{l}\text { Sand Run gulch at } \\
\text { Highway } 95^{4}\end{array}$ & 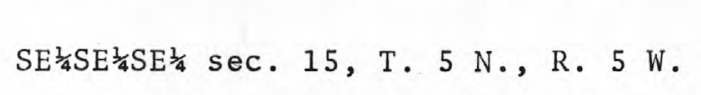 & 69.4 & 39 & $(555)$ & 827 & 10.0 \\
\hline Sand Run gulch at mouth ${ }^{3,4}$ & $\mathrm{NWW}_{\frac{1}{4}} \mathrm{NW}^{\frac{1}{4}} \mathrm{NW}^{\frac{1}{4}} \mathrm{sec} .36, \mathrm{~T} .6 \mathrm{~N} ., \mathrm{R} .6 \mathrm{~W}$. & 76.5 & 42 & 562 & 842 & 8.0 \\
\hline
\end{tabular}

$1(n)=$ estimated from specific conductance value using the formula: dissolved solids $=0.67 \mathrm{x}$ specific conductance. 2 Does not include drains, sloughs, bypasses, etc.

3 Standard chemical analysis available.

4 Not tributary to the Boise River. 

